Check for updates

Cite this: Phys. Chem. Chem. Phys., 2020, 22, 13092

Received 19th April 2020 Accepted 27th May 2020

DOI: $10.1039 / \mathrm{d} 0 \mathrm{cp} 02110 \mathrm{e}$

rsc.li/pccp

\title{
Microhydration of protonated biomolecular building blocks: protonated pyrimidine $\dagger$
}

\begin{abstract}
Kuntal Chatterjee (D) and Otto Dopfer (D)*
Protonation and hydration of biomolecules govern their structure, conformation, and function. Herein, we explore the microhydration structure in mass-selected protonated pyrimidine-water clusters $\left(\mathrm{H}^{+}\right.$Pym $\left.-\mathrm{W}_{n}, n=1-4\right)$ by a combination of infrared photodissociation spectroscopy (IRPD) between 2450 and $3900 \mathrm{~cm}^{-1}$ and density functional theory (DFT) calculations at the dispersion-corrected B3LYP-D3/aug-cc-pVTZ level. We further present the IR spectrum of $\mathrm{H}^{+} \mathrm{Pym}-\mathrm{N}_{2}$ to evaluate the effect of solvent polarity on the intrinsic molecular parameters of $\mathrm{H}^{+} \mathrm{Pym}$. Our combined spectroscopic and computational approach unequivocally shows that protonation of Pym occurs at one of the two equivalent basic ring $\mathrm{N}$ atoms and that the ligands in $\mathrm{H}^{+}$Pym $-\mathrm{L}\left(\mathrm{L}=\mathrm{N}_{2}\right.$ or $\left.\mathrm{W}\right)$ preferentially form linear $\mathrm{H}$-bonds to the resulting acidic $\mathrm{NH}$ group. Successive addition of water ligands results in the formation of a $\mathrm{H}$-bonded solvent network which increasingly weakens the $\mathrm{NH}$ group. Despite substantial activation of the $\mathrm{N}-\mathrm{H}$ bond upon microhydration, no intracluster proton transfer occurs up to $n=4$ because of the balance of relative proton affinities of Pym and $W_{n}$ and the involved solvation energies. Comparison to neutral Pym $-W_{n}$ clusters reveals the drastic effects of protonation on microhydration with respect to both structure and interaction strength.
\end{abstract}

\section{Introduction}

Nucleobases, the building blocks of the genetic materials RNA and DNA, are derived from two different aromatic N-heterocycles, pyrimidine (Pym, $\mathrm{C}_{4} \mathrm{H}_{4} \mathrm{~N}_{2}$, 1,3-diazine, 1,3-diazabenzene) and purine. ${ }^{1,2}$ Pyrimidine bases include uracil, thymine, and cytosine, whereas adenine and guanine belong to purines. The protonated form of these nucleobases plays a key role in physiological media, ${ }^{3-16}$ for example in RNA catalysis. ${ }^{17}$ The site of protonation as well as the base pairing involving the additional proton leads to structural motifs, which are crucial for the stability of DNA structures. $^{18-20}$ For example, the interaction between cytosine and protonated cytosine stabilizes the d(CCCAAT) tetraplex. $^{21}$ Protonated cytosine further participates in Hoogsteen base pairing, which is sensitive to the $\mathrm{pH}$ value. ${ }^{22}$ Such pairing involving a proton is critical because it can alter structure and function of DNA, often resulting in mutagenesis. ${ }^{23,24}$

The stability and reactivity of biomolecules in vivo are generally controlled by their (micro-)hydration environment. ${ }^{25}$ Thus, water $\left(\mathrm{W}, \mathrm{H}_{2} \mathrm{O}\right)$ is considered as an integral part of these bioactive compounds (biological or interfacial water). ${ }^{26-35}$ For example, a combined X-ray crystallographic and NMR study on a model dodecamer B-DNA complex shows that the minor

Institut für Optik und Atomare Physik, TU Berlin, Hardenbergstr. 36, 10623 Berlin, Germany.E-mail: dopfer@physik.tu-berlin.de

$\dagger$ Electronic supplementary information (ESI) available. See DOI: 10.1039/d0cp02110e groove is more extensively hydrated than the major groove. ${ }^{36,37}$ The surface water molecules are strikingly influential for DNA structure and the recognition of proteins and drugs by balancing enthalpic and entropic contributions to the overall free energy. ${ }^{38-41}$ Furthermore, water acts as a transport medium in interbase proton transfer reactions. ${ }^{26,27,30,42-45}$

The molecular picture of the hydration network around small building blocks provides information about their macroscopic function. Mass spectrometry coupled with vibrational spectroscopy and quantum chemical calculations has shown to be a powerful strategic approach for yielding such microscopic insight at the molecular level. ${ }^{16,46-53}$ Despite several mass spectrometric studies ${ }^{54-57}$ and very limited spectroscopic data on more complex pyrimidine molecules, ${ }^{46}$ the spectroscopic knowledge on the structure of even simple protonated building blocks of nucleobases within their microhydration environment remains elusive. ${ }^{14,15,58,59}$ In addition to biochemical topics, the Pym..WW interaction is also relevant for astrochemical applications related to prebiotic synthesis of DNA/RNA bases. For example, it has been reported that UV irradiation of pyrimidine: $\mathrm{H}_{2} \mathrm{O}$ ices leads to the formation of uracil, ${ }^{60-62}$ which has been found in carbonaceous chondrites ${ }^{63-65}$ and thus provides hints about the enigmatic prebiotic chemistry of the nucleobase...water interaction.

Knowledge of protonated pyrimidine-water clusters $\left(\mathrm{H}^{+} \mathrm{Pym}-\mathrm{W}_{n}\right)$ offers the opportunity to understand their role in more complex biomolecular architectures as well as the 
mechanistic chemical route toward uracil. Previous mass spectrometric (ion mobility, thermochemical equilibrium measurements, multiphoton ionization of neutral clusters) and computational studies of $\mathrm{H}^{+}$Pym and $\mathrm{H}^{+} \mathrm{Pym}-\mathrm{W}_{n}$ clusters suggest that protonation occurs at one of the two heterocyclic basic $\mathrm{N}$ atoms and that the water clusters form an ionic hydrogen-bonded (H-bonded) network attached to the resulting $\mathrm{NH}$ group. ${ }^{66-68}$ In addition, mass spectrometric experiments suggest that bimolecular dissociative proton transfer according to

$$
\mathrm{H}^{+} \text {Pym }-\mathrm{W}_{n-1}+\mathrm{W} \rightarrow \text { Pym }+\mathrm{W}_{n} \mathrm{H}^{+}
$$

becomes exothermic for clusters larger than the critical size $n \geq 4,{ }^{66,67}$ because at this cluster size the proton affinity of $\mathrm{W}_{n}$ clusters (PA = 691, 808, 862, 900, 904, $908 \mathrm{~kJ} \mathrm{~mol}^{-1}$ for $\left.n=1-6\right)$ exceeds that of Pym $\left(\mathrm{PA}=886 \mathrm{~kJ} \mathrm{~mol}^{-1}\right) \cdot{ }^{69-73}$ However, all structures calculated so far for $\left[\mathrm{Pym}-\mathrm{W}_{4}\right] \mathrm{H}^{+}$are of the type $\mathrm{H}^{+} \mathrm{Pym}-\mathrm{W}_{4},{ }^{66,67}$ i.e. no intracluster proton transfer (ICPT) from $\mathrm{H}^{+}$Pym to $\mathrm{W}_{n}$ occurs in the size range $n \leq 4$ due to favourable solvation energies compared to $\mathrm{Pym}-\mathrm{H}^{+} \mathrm{W}_{4}$ which compensate the difference in proton affinity. In general, no spectroscopic information is available to support these structures and binding motifs in $\left[\mathrm{Pym}-\mathrm{W}_{n}\right] \mathrm{H}^{+}$. Such spectroscopic data provide much more reliable structural information than the bare combination of mass spectrometry and quantum chemistry, which often leads to wrong conclusions, as recently demonstrated for the example of the microhydrated naphthalene cation. $^{74,75}$ To this end, we report herein the IR signatures of mass selected $\left[\mathrm{Pym}-\mathrm{W}_{n}\right] \mathrm{H}^{+}$clusters and interpret them with the aid of reliable density functional theory (DFT) calculations. This approach has recently been applied in our laboratory to a variety of microhydrated protonated aromatic ions and radical cations. ${ }^{4-51,53,76-87}$ A particular question to be addressed is the degree of $\mathrm{N}-\mathrm{H}$ bond activation and propensity for ICPT to solvent as a function of the degree of hydration, which has been observed for a number of protonated aromatic molecules and cations above a critical hydration size $\left(n \geq n_{\mathrm{c}}\right) .^{50,85,88-91}$ Furthermore, the study of $\mathrm{H}^{+}$Pym- $\mathrm{N}_{2}$ elucidates the impact of solvent polarity on the physical properties of $\mathrm{H}^{+}$Pym and its solvation pattern. Comparison with neutral Pym- $\mathrm{W}_{n}$ clusters $^{92,93}$ reveals the drastic effects of protonation on the microhydration process, with respect to both structure and interaction strength.

\section{Experimental and computational methods}

IRPD spectra of mass selected $\mathrm{H}^{+}$Pym- $\mathrm{L}_{n}$ clusters with $\mathrm{L}=\mathrm{W}$ $(n=1-4)$ and $\mathrm{L}=\mathrm{N}_{2}(n=1)$ are obtained in a tandem quadrupole mass spectrometer coupled to an electron ionization (EI) source and an octopole ion guide. ${ }^{52,94}$ In short, the clusters are produced in a pulsed supersonic plasma expansion by electron or chemical ionization and subsequent clustering reactions in the high-pressure region of the expansion. A mixture of $\mathrm{N}_{2}$ and $5 \% \mathrm{H}_{2} / \mathrm{He}$ in a 1:1 ratio is guided as a carrier gas (8-10 bar) through a sample reservoir containing liquid Pym (Sigma-Aldrich, $\geq 98 \%$, used without further purification, heated to $60{ }^{\circ} \mathrm{C}$ ). Distilled water is added to the gas line to produce hydrated clusters. The desired $\mathrm{H}^{+} \mathrm{Pym}-\mathrm{L}_{n}$ parent clusters are massselected in the first quadrupole and irradiated in the adjacent octopole with a tunable IR laser pulse $\left(\nu_{\mathrm{IR}}, 10 \mathrm{~Hz}, 2-5 \mathrm{~mJ}\right.$, bandwidth $2 \mathrm{~cm}^{-1}$ ) of an optical parametric oscillator pumped by a Q-switched Nd:YAG laser. Calibration of $\nu_{\mathrm{IR}}$ is achieved by a wavemeter. Resonant vibrational excitation followed by intracluster vibrational redistribution leads to the loss of a single water or $\mathrm{N}_{2}$ ligand. Loss of Pym is not observed. Resulting $\mathrm{H}^{+}$Pym- $\mathrm{L}_{n-1}$ fragment ions are mass-selected by the second quadrupole and recorded with a Daly detector as a function of $\nu_{\text {IR }}$ to derive the IRPD spectrum of the parent cluster. The IRPD yield is linearly normalized for laser intensity variations measured with a pyroelectric detector. The separation of the laserinduced dissociation signal from the signal generated by metastable decay is achieved by triggering the ion source at twice the laser repetition rate and subtracting signals from alternating triggers. The observed peak widths of vibrational transitions are mainly due to unresolved rotational structure, lifetime broadening, sequence hot bands involving inter- and intramolecular modes, and possibly contributions from different structural isomers.

To analyze the IRPD spectra, conceivable $\mathrm{H}^{+} \mathrm{Pym}-\mathrm{L}_{n}$ clusters are characterized at the B3LYP-D3/aug-cc-pVTZ level. ${ }^{95}$ This dispersion-corrected functional accounts well for the electrostatic, induction, and dispersion forces and IR spectra of the investigated clusters. ${ }^{49-51,74,77-80,83,86}$ For instance, there is quantitative agreement between the binding energies computed for $\mathrm{W}_{2}$ and $\mathrm{H}^{+} \mathrm{Pym}-\mathrm{W}\left(D_{0}=1103\right.$ and $\left.5854 \mathrm{~cm}^{-1}\right)$ and their experimental values $\left(D_{0}=1105 \pm 10 \mathrm{~cm}^{-1}\right.$ and $-\Delta H^{0}=5840 \pm$ $\left.350 \mathrm{~cm}^{-1}\right)^{67,96}$ indicating that effects of self-interaction errors present in several density functional theory approximations do not play a major role in the evaluation of binding energies using our approach. ${ }^{97}$ For comparison, neutral Pym, W, and Pym-W are also computed to understand the effect of protonation on their molecular properties. All coordinates are allowed to relax during the search for stationary points, and their nature as minima or transition states are verified by harmonic frequency analysis. Harmonic intramolecular vibrational frequencies are subjected to a linear scaling factor of 0.96221 , derived from a comparison of computed $\mathrm{CH}$ and $\mathrm{OH}$ stretch frequencies of neutral Pym and $\mathrm{W}$ with their measured values. ${ }^{98-101}$ Scaled harmonic IR stick spectra are convoluted with a Gaussian line shape $\left(\mathrm{fwhm}=10 \mathrm{~cm}^{-1}\right)$ for convenient comparison with the experimental spectra. All relative energies $\left(E_{\mathrm{e}}\right)$ and equilibrium dissociation energies $\left(D_{\mathrm{e}}\right)$ are corrected for harmonic zero-point vibrational energy to derive $E_{0}$ and $D_{0}$ values. Gibbs free energies $(G)$ are reported for $T=298.15 \mathrm{~K}$. If not stated otherwise, the total intermolecular dissociation energies $\left(D_{0}\right)$ are determined with respect to the molecular $\mathrm{H}^{+}$Pym and $\mathrm{W}$ monomer fragments. Previous experience with the employed DFT level demonstrates that basis set superposition errors are less than $1 \%,{ }^{49,80}$ and thus they are not considered further here. Cartesian coordinates of all relevant structures and their energies are available in the ESI. $\dagger$ The atomic charge distribution and second-order perturbation energies $\left(E^{(2)}\right)$ of the 
donor-acceptor orbital interactions involved in the H-bonds are evaluated using the natural bond orbital (NBO) approach. ${ }^{102}$ To further estimate the strength of these H-bonds, noncovalent interaction (NCI) calculations are performed by analyzing the reduced gradient of the electron density, $s(\rho) \sim|\operatorname{grad}(\rho)| / \rho^{4 / 3}$, as a function of electron density $\rho$ oriented by the sign of second eigenvalue $\lambda_{2}$ of the Hessian, $\rho^{*}=\rho \operatorname{sign}\left(\lambda_{2}\right) .{ }^{103,104}$ The strength of the intermolecular bonds can be estimated by comparing the magnitude of the $-\rho^{*}$ value.

\section{Results and discussion}

Fig. 1 displays the experimental IRPD spectra of $\mathrm{H}^{+} \mathrm{Pym}-\mathrm{L}_{n}$ recorded between 2450 and $3900 \mathrm{~cm}^{-1}$ in the $\mathrm{H}^{+}$Pym- $\mathrm{L}_{n-1}$ fragment channel. The positions and widths of the bands observed are listed in Table 1, along with the vibrational and isomer assignments based on scaled harmonic frequencies. The spectral range covers the $\mathrm{OH}\left(\nu_{\mathrm{OH}}\right), \mathrm{NH}\left(\nu_{\mathrm{NH}}\right)$, and $\mathrm{CH}\left(\nu_{\mathrm{CH}}\right)$ stretch fundamentals, providing detailed information about the protonation site and the solvation network. Peaks A-C between 3600 and $3800 \mathrm{~cm}^{-1}$ correspond to free $\mathrm{OH}$ stretch modes $\left(\nu_{\mathrm{OH}}^{\mathrm{f}}\right)$, peaks $\mathrm{D}$ in the $3200-3500$ range are due to

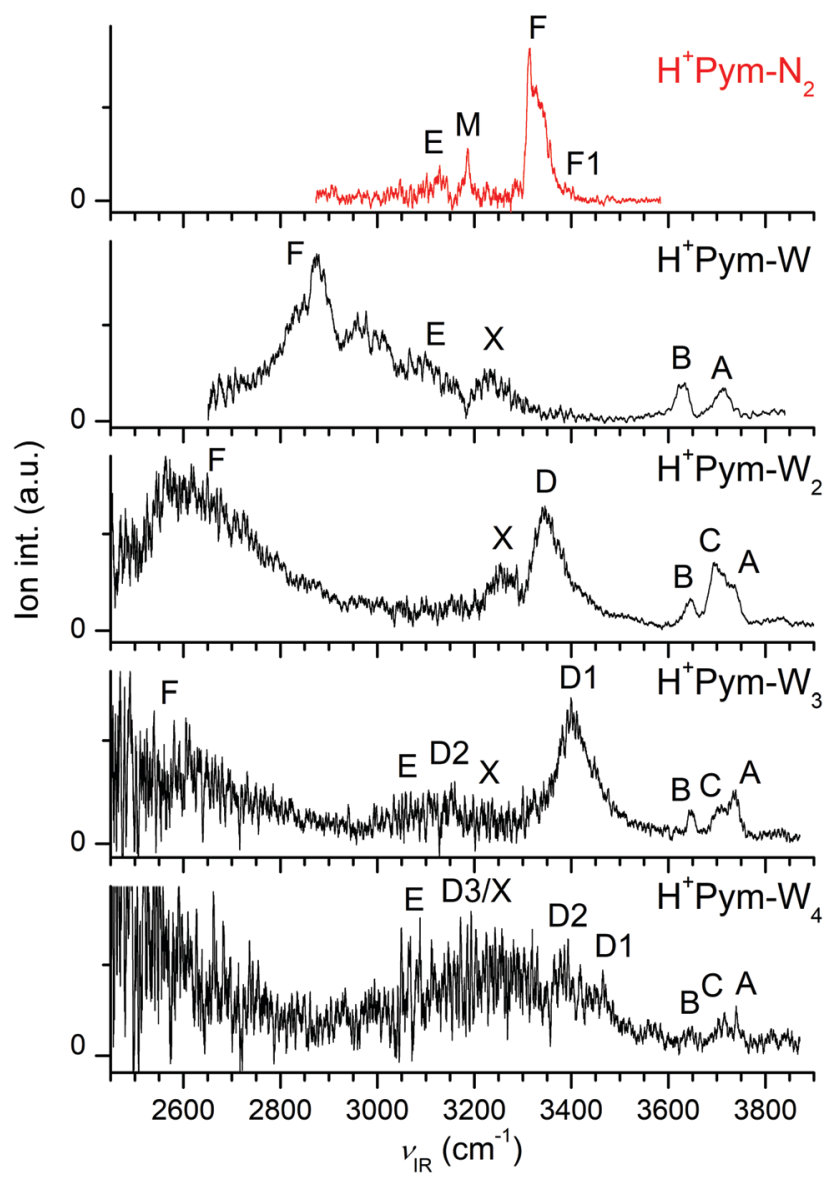

Fig. 1 IRPD spectra of $\mathrm{H}^{+}$Pym $-\mathrm{L}_{n}$ clusters with $\mathrm{L}=\mathrm{W}(n=1-4)$ and $\mathrm{L}=\mathrm{N}_{2}$ $(n=1)$ recorded in the $H^{+} P y m-L_{n-1}$ fragment channel. The positions, widths, and vibrational and isomer assignments of the transitions observed are listed in Table 1.
H-bonded $\mathrm{OH}$ stretch modes $\left(\nu_{\mathrm{OH}}^{\mathrm{b}}\right)$, bands $\mathrm{E}$ near $3200 \mathrm{~cm}^{-1}$ arise from aromatic $\mathrm{CH}$ stretch modes $\left(\nu_{\mathrm{CH}}\right)$, and bands $\mathrm{F}$ are associated with free and bound NH stretch fundamentals $\left(\nu_{\mathrm{NH}}^{\mathrm{f} / \mathrm{b}}\right)$. To assign the spectra to structures, we explore possible isomers of $\mathrm{H}^{+} \mathrm{Pym}$ and $\mathrm{H}^{+}$Pym- $\mathrm{L}_{n}$ by DFT calculations and compare their predicted IR spectra to the experimental ones.

\subsection{Pym, $\mathrm{H}^{+}$Pym, and $\mathrm{W}$}

Pym has a planar equilibrium structure with $C_{2 \mathrm{v}}$ symmetry in its ${ }^{1} \mathrm{~A}_{1}$ ground electronic state (Fig. 2), as revealed from microwave, IR, and Raman spectroscopy, X-ray crystallography, and quantum chemical calculations. ${ }^{98,99,105-109}$ Our calculated geometric and vibrational parameters compare favourably with experimental values (Table $\mathrm{S} 1$ in the ESI $\dagger$ ). Furthermore, the measured proton affinity is comparable to the computed one assuming N-protonation ( $\left.\mathrm{PA}=886 v s .890 \mathrm{~kJ} \mathrm{~mol}^{-1}\right),{ }^{69}$ confirming the reliability of the current computational approach.

Protonation of Pym reduces its symmetry from $C_{2 \mathrm{v}}$ to $C_{\mathrm{s}}$ in its ground electronic state $\left({ }^{1} \mathrm{~A}_{1}\right)$. Protonation can occur either at one of the two equivalent ring $\mathrm{N}$ atoms or at the ring $\mathrm{C}$ atoms (carbenium ions) (Fig. S1 in the ESI $\dagger$ ). C-protonation results in an aliphatic $\mathrm{CH}_{2}$ group, and the corresponding $\nu_{\mathrm{CH}_{2}}$ modes are calculated below $2850 \mathrm{~cm}^{-1}$ with high IR activity for all isomers ( $>100 \mathrm{~km} \mathrm{~mol}^{-1}$, Fig. S2 in the ESI $\dagger$ ). All three nonequivalent carbenium isomers are very high in relative energy. Because C-protonation strongly perturbs the aromatic ring, they are less stable than the N-protonated isomer by at least $E_{0} \geq 200 \mathrm{~kJ} \mathrm{~mol}^{-1}$, consistent with previous mass spectrometric and computational findings. ${ }^{67,68}$ Thus, we mainly focus herein on the N-protonated isomer denoted $\mathrm{H}^{+}$Pym and do not consider carbenium isomers in detail further. The effect of N-protonation is rather large on the ring skeleton (up to $\Delta r_{\mathrm{CC} / \mathrm{CN}}<25 \mathrm{~mA}$ ), while the peripheral $\mathrm{C}-\mathrm{H}$ bonds are less affected $\left(\Delta r_{\mathrm{CH}}<5 \mathrm{~mA}\right)$ (Fig. 2 and Table S1 in the ESI $\dagger)$. Nearly half of the positive charge resides on the additional proton $(0.45 e)$, while the remaining partial charge is delocalized over the aromatic ring (mostly on the peripheral hydrogen atoms, Fig. S3 in the ESI $\dagger$ ). Protonation increases the average $\nu_{\mathrm{CH}}$ frequency with a concomitant decrease in total IR oscillator strength $\left(\Delta \nu_{\mathrm{CH}}=41 \mathrm{~cm}^{-1}, \Delta I_{\text {total }}=-20 \mathrm{~km} \mathrm{~mol}^{-1}\right)$, and the free NH stretch mode of $\mathrm{H}^{+}$Pym calculated at $\nu_{\mathrm{NH}}^{\mathrm{f}}=3396 \mathrm{~cm}^{-1}$ is the dominant IR transition in the $3 \mu \mathrm{m}$ range $\left(I_{\mathrm{NH}}=159 \mathrm{~km} \mathrm{~mol}^{-1}\right.$, Fig. 3).

The $\mathrm{O}-\mathrm{H}$ bond parameters of neutral $\mathrm{W}$ in its ${ }^{1} \mathrm{~A}_{1}$ ground state $\left(r_{\mathrm{OH}}=0.9619 \AA, \nu_{1 / 3}=3653 / 3752 \mathrm{~cm}^{-1}\right)$ are close to the corresponding experimental values $\left(0.9578 \AA\right.$, $\left.3657 / 3756 \mathrm{~cm}^{-1}\right) .{ }^{101,110}$ The minor discrepancy in the $\nu_{\mathrm{OH}}$ modes $\left(\Delta \nu_{\mathrm{OH}}=-4 \mathrm{~cm}^{-1}\right)$ arises because of the simultaneous consideration of the $\nu_{\mathrm{CH}}$ modes of Pym and the $\nu_{\mathrm{OH}}$ modes of $\mathrm{W}$ when determining the single scaling factor.

\section{$3.2 \mathbf{H}^{+}$Pym- $\mathbf{N}_{2}$}

We consider in Fig. 2 all relevant binding motifs for $\mathrm{N}_{2}$ in $\mathrm{H}^{+}$Pym- $\mathrm{N}_{2}$ with $\mathrm{N}$-protonated Pym. In the most stable $\mathrm{H}^{+}$Pym- $\mathrm{N}_{2}(\mathrm{H})$ global minimum $\left(D_{0}=1530 \mathrm{~cm}^{-1}\right), \mathrm{N}_{2}$ is H-bonded to the acidic NH group $\left(R_{\mathrm{NH} \cdots \mathrm{N}_{2}}=2.061 \AA\right)$, whereas in the much less stable $\mathrm{H}^{+} \mathrm{Pym}-\mathrm{N}_{2}(\pi)$ local minimum a $\pi$-bonded $\mathrm{N}_{2}$ ligand is located above the aromatic ring $\left(D_{0}=858 \mathrm{~cm}^{-1}\right)$. 
Table 1 Positions, widths (fwhm in parentheses), and suggested vibrational and isomer assignments of the transitions observed in the IRPD spectra of $\mathrm{H}^{+}$Pym- $\mathrm{L}_{n}$ clusters (Fig. 1) to the most stable isomers obtained at the B3LYP-D3/aug-cc-pVTZ level

\begin{tabular}{|c|c|c|c|c|}
\hline & Exp. $\left(\mathrm{cm}^{-1}\right)$ & Calc. $\left(\mathrm{cm}^{-1}\right)$ & Mode & Isomer \\
\hline $\mathrm{W}$ & $\begin{array}{l}3756^{a} \\
3657^{a}\end{array}$ & $\begin{array}{l}3752\left(63, b_{2}\right) \\
3653\left(5, a_{1}\right)\end{array}$ & $\begin{array}{l}\nu_{3} \\
\nu_{1}\end{array}$ & $\begin{array}{l}W \\
W\end{array}$ \\
\hline $\mathrm{W}_{2}$ & $\begin{array}{l}3746^{b} \\
3735^{b} \\
3654^{b} \\
3601^{b}\end{array}$ & $\begin{array}{l}3743\left(84, a^{\prime \prime}\right) \\
3724\left(86, a^{\prime}\right) \\
3648\left(10, a^{\prime}\right) \\
3537\left(341, a^{\prime}\right)\end{array}$ & $\begin{array}{l}\nu_{3} \\
\nu_{\mathrm{f}} \\
\nu_{1} \\
\nu_{\mathrm{OH}}^{\mathrm{b}}\end{array}$ & $\begin{array}{l}\mathrm{W}_{2} \\
\mathrm{~W}_{2} \\
\mathrm{~W}_{2} \\
\mathrm{~W}_{2}\end{array}$ \\
\hline Pym & $\begin{array}{l}3074^{c} \\
3050^{c} \\
3039^{c} \\
3002^{c}\end{array}$ & $\begin{array}{l}3076\left(9, a_{1}\right) \\
3043\left(13, a_{1}\right) \\
3032\left(18, b_{2}\right) \\
3029\left(14, a_{1}\right)\end{array}$ & $\begin{array}{l}\nu_{\mathrm{C}_{5} \mathrm{H}} \\
\nu_{\mathrm{C}_{2} \mathrm{H}} \\
\nu_{\mathrm{C}_{4} \mathrm{H} / \mathrm{C}_{6} \mathrm{H}}(\mathrm{as}) \\
\nu_{\mathrm{C}_{4} \mathrm{H} / \mathrm{C}_{6} \mathrm{H}}(\mathrm{s})\end{array}$ & $\begin{array}{l}\text { Pym } \\
\text { Pym } \\
\text { Pym } \\
\text { Pym }\end{array}$ \\
\hline $\mathrm{H}^{+} \mathrm{Pym}$ & $3391 \pm 3$ & $\begin{array}{l}3396\left(159, a^{\prime}\right) \\
3106\left(14, a^{\prime}\right) \\
3095\left(8, a^{\prime}\right) \\
3079\left(10, a^{\prime}\right) \\
3065\left(2, a^{\prime}\right)\end{array}$ & $\begin{array}{l}\nu_{\mathrm{NH}}^{\mathrm{f}} \\
\nu_{\mathrm{CH}} \\
\nu_{\mathrm{CH}} \\
\nu_{\mathrm{CH}} \\
\nu_{\mathrm{CH}}\end{array}$ & $\begin{array}{l}\mathrm{H}^{+} \mathrm{Pym} \\
\mathrm{H}^{+} \mathrm{Pym} \\
\mathrm{H}^{+} \mathrm{Pym} \\
\mathrm{H}^{+} \mathrm{Pym} \\
\mathrm{H}^{+} \mathrm{Pym}\end{array}$ \\
\hline $\mathrm{H}^{+} \mathrm{Pym}-\mathrm{N}_{2}$ & $\begin{array}{l}\text { F1 } 3395(14) \\
\text { F } 3313(41) \\
\text { M } 3186(7) \\
\text { E } 3127(45)\end{array}$ & $\begin{array}{l}3400(153) \\
3277\left(753, a^{\prime}\right) \\
3219 \\
3105\left(12, a^{\prime}\right), 3106(13) \\
3094\left(6, a^{\prime}\right), 3095(7) \\
3079\left(8, a^{\prime}\right), 3080(9) \\
3065\left(2, a^{\prime}\right), 3065(2)\end{array}$ & $\begin{array}{l}\nu_{\mathrm{NH}}^{\mathrm{f}} \\
\nu_{\mathrm{NH}}^{\mathrm{b}} \\
2 \beta_{\mathrm{NH}} \\
\nu_{\mathrm{CH}} \\
\nu_{\mathrm{CH}} \\
\nu_{\mathrm{CH}} \\
\nu_{\mathrm{CH}}\end{array}$ & 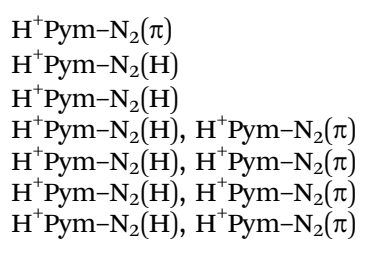 \\
\hline $\mathrm{H}^{+}$Pym-W & $\begin{array}{l}\text { A } 3717(35) \\
\text { B } 3633(30) \\
\text { X } 3233(68) \\
\text { E } 3100(115) \\
\text { F } 2875(207)\end{array}$ & $\begin{array}{l}3722\left(147, a^{\prime \prime}\right) \\
3637\left(57, a^{\prime}\right) \\
3220 / 3247 \\
3105\left(8, a^{\prime}\right) \\
3093\left(6, a^{\prime}\right) \\
3080\left(5, a^{\prime}\right) \\
3063\left(1, a^{\prime}\right) \\
2933\left(1712, a^{\prime}\right)\end{array}$ & $\begin{array}{l}\nu_{3} \\
\nu_{1} \\
2 \beta_{\mathrm{OH}} / 2 \beta_{\mathrm{NH}} \\
\nu_{\mathrm{CH}} \\
\nu_{\mathrm{CH}} \\
\nu_{\mathrm{CH}} \\
\nu_{\mathrm{CH}} \\
\nu_{\mathrm{NH}}^{\mathrm{b}}\end{array}$ & $\begin{array}{l}\mathrm{H}^{+} \text {Pym-W(H) } \\
\mathrm{H}^{+} \text {Pym-W(H) } \\
\mathrm{H}^{+} \text {Pym-W(H) } \\
\mathrm{H}^{+} \text {Pym-W(H) } \\
\mathrm{H}^{+} \text {Pym-W(H) } \\
\mathrm{H}^{+} \text {Pym-W(H) } \\
\mathrm{H}^{+} \text {Pym-W(H) } \\
\mathrm{H}^{+} \text {Pym-W(H) }\end{array}$ \\
\hline $\mathrm{H}^{+} \mathrm{Pym}-\mathrm{W}_{2}$ & $\begin{array}{l}\text { A } 3730(27) \\
\text { C } 3698(35) \\
\text { B } 3645(24) \\
\text { D } 3340(75) \\
\text { X } 3250 \text { (60) } \\
\text { F } 2605 \text { (broad) }\end{array}$ & $\begin{array}{l}3734(122) \\
3706(113) \\
3645(31) \\
3275(1008) \\
3195,3261 / 3272 \\
2658(2701)\end{array}$ & $\begin{array}{l}\nu_{3} \\
\nu_{\mathrm{f}} \\
\nu_{1} \\
\nu_{\mathrm{OH}} \\
2 \beta_{\mathrm{OH}} / 2 \beta_{\mathrm{NH}} \\
\nu_{\mathrm{NH}}^{\mathrm{b}}\end{array}$ & 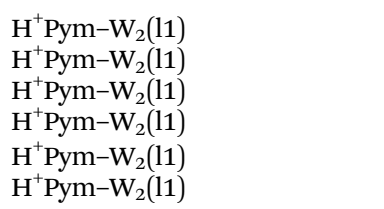 \\
\hline $\mathrm{H}^{+} \mathrm{Pym}-\mathrm{W}_{3}$ & $\begin{array}{l}\text { A } 3736(23) \\
\text { C } 3709(30) \\
\text { B } 3647(16) \\
\text { D1 } 3399(80) \\
\text { X } 3228 \text { (broad) } \\
\text { D2 } 3152 \text { (100) } \\
\text { E } 3105 \text { (broad) } \\
\text { F <2450 (broad) }\end{array}$ & $\begin{array}{l}3739\left(224, a^{\prime \prime}\right) \\
3740(115) \\
3712(83), 3710(112) \\
3649\left(46, a^{\prime}\right) \\
3649(24) \\
3397\left(1300, a^{\prime \prime}\right), 3359\left(534, a^{\prime}\right) \\
3373(690) \\
3180,3212 / 3215,3185 \\
3068(1499) \\
3104\left(4, a^{\prime}\right), 3105(5) \\
2312\left(3640, a^{\prime}\right), 2497(3286)\end{array}$ & $\begin{array}{l}\nu_{3} \\
\nu_{3} \\
\nu_{\mathrm{f}} \\
\nu_{1} \\
\nu_{1} \\
\nu_{\mathrm{OH}}^{\mathrm{b}} \\
\nu_{\mathrm{OH}}^{\mathrm{b}} \\
2 \beta_{\mathrm{OH}} \\
\nu_{\mathrm{OH}}^{\mathrm{b}} \\
\nu_{\mathrm{CH}} \\
\nu_{\mathrm{NH}}^{\mathrm{b}}\end{array}$ & 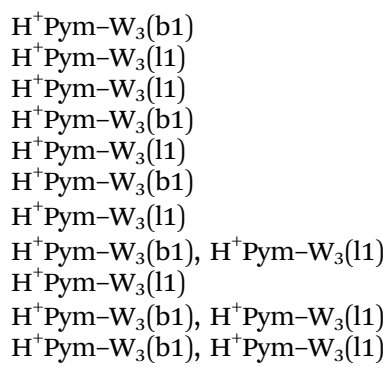 \\
\hline $\mathrm{H}^{+} \mathrm{Pym}-\mathrm{W}_{4}$ & $\begin{array}{l}\text { A } 3740(8) \\
\text { C } 3716(17) \\
\text { B } 3648(20) \\
\text { D1 } 3464(70) \\
\text { D2 } 3393(52) \\
\text { D3 } 3200(170) \\
\text { X } 3200(170) \\
\text { E } 3087(50)\end{array}$ & $\begin{array}{l}3715\left(82, a^{\prime}\right) \\
3741(110), 3739(114) \\
3715\left(94, a^{\prime}\right), 3712\left(197, a^{\prime \prime}\right) \\
3698(89) \\
3630\left(17, a^{\prime}\right) \\
3650(21), 3649(24) \\
3529\left(439, a^{\prime}\right), 3510\left(370, a^{\prime \prime}\right) \\
3423(999), 3380(380) \\
3348(1043) \\
3310\left(900, a^{\prime}\right), 3304\left(718, a^{\prime \prime}\right) \\
3209,3199 \\
3103\left(3, a^{\prime}\right) \\
3063(42)\end{array}$ & $\begin{array}{l}\nu_{3} \\
\nu_{3} \\
\nu_{\mathrm{f}} \\
\nu_{\mathrm{f}} \\
\nu_{1} \\
\nu_{1} \\
\nu_{\mathrm{OH}}^{\mathrm{b}} \\
\nu_{\mathrm{OH}}^{\mathrm{b}} \\
\nu_{\mathrm{OH}}^{\mathrm{b}} \\
\nu_{\mathrm{OH}}^{\mathrm{b}} 2 \beta_{\mathrm{OH}} \\
2 \beta_{\mathrm{OH}} \\
\nu_{\mathrm{CH}} \\
\nu_{\mathrm{CH}}^{\mathrm{b}}\end{array}$ & $\begin{array}{l}\mathrm{H}^{+} P y m-W_{4}(\mathrm{r}) \\
\mathrm{H}^{+} P y m-W_{4}(\mathrm{~b} 2) \\
\mathrm{H}^{+} P y m-W_{4}(\mathrm{r}) \\
\mathrm{H}^{+} \mathrm{Pym}-\mathrm{W}_{4}(\mathrm{~b} 2) \\
\mathrm{H}^{+} \mathrm{Pym}-\mathrm{W}_{4}(\mathrm{r}) \\
\mathrm{H}^{+} \mathrm{Pym}-\mathrm{W}_{4}(\mathrm{~b} 2) \\
\mathrm{H}^{+} \mathrm{Pym}-\mathrm{W}_{4}(\mathrm{r}) \\
\mathrm{H}^{+} \mathrm{Pym}-\mathrm{W}_{4}(\mathrm{~b} 2) \\
\mathrm{H}^{+} \mathrm{Pym}-\mathrm{W}_{4}(\mathrm{~b} 2) \\
\mathrm{H}^{+} \mathrm{Pym}-\mathrm{W}_{4}(\mathrm{r}) \\
\mathrm{H}^{+} \mathrm{Pym}-\mathrm{W}_{4}(\mathrm{r}) \\
\mathrm{H}^{+} \mathrm{Pym}-\mathrm{W}_{4}(\mathrm{r}) \\
\mathrm{H}^{+} \mathrm{Pym}-\mathrm{W}_{4}(\mathrm{~b} 2)\end{array}$ \\
\hline
\end{tabular}


Table 1 (continued)

\begin{tabular}{llll}
\hline Exp. $\left(\mathrm{cm}^{-1}\right)$ & Calc. $\left(\mathrm{cm}^{-1}\right)$ & Mode & Isomer \\
\hline $\mathrm{F}<2450$ (broad) & $2274(3300)$ & $\nu_{\mathrm{NH}}^{\mathrm{b}}$ & $\mathrm{H}^{+} \mathrm{Pym}-\mathrm{W}_{4}(\mathrm{~b} 2)$ \\
$\nu_{\mathrm{NH}}^{\mathrm{b}}$ & $\mathrm{H}^{+} \mathrm{Pym}-\mathrm{W}_{4}(\mathrm{r})$
\end{tabular}

${ }^{a}$ Ref. $101 .{ }^{b}$ Ref. $118-120 .{ }^{c}$ Ref. 98-100.
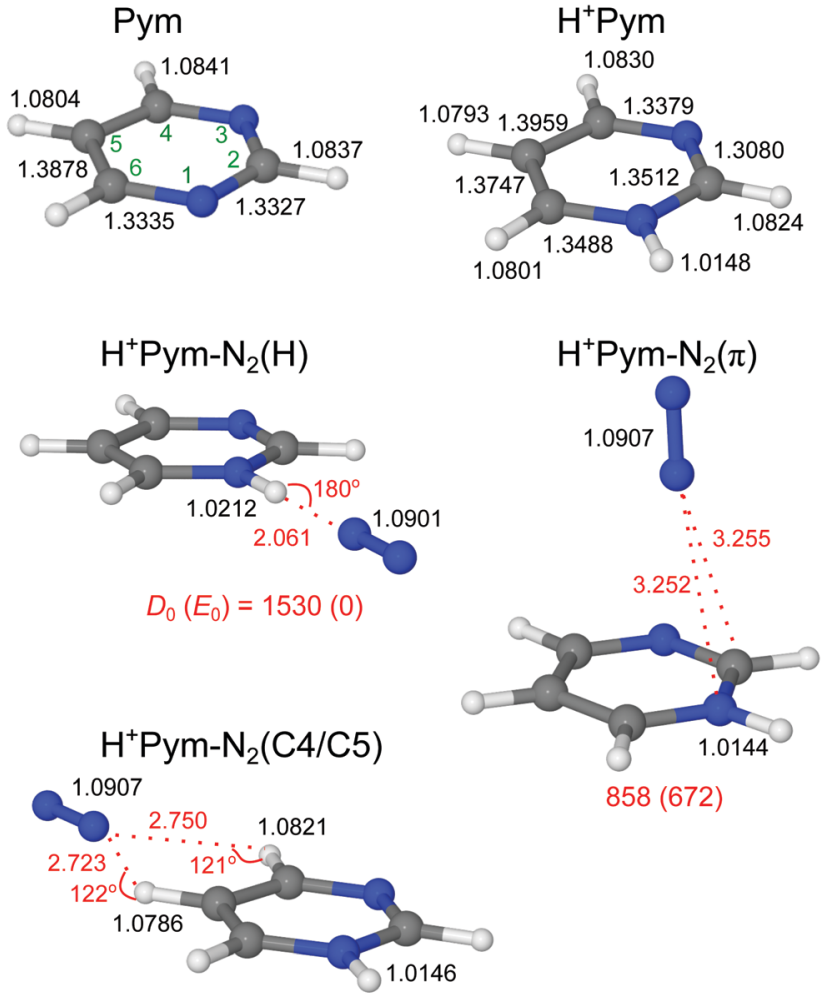

$703(827)$

Fig. 2 Optimized geometries of Pym (along with atomic numbering), $\mathrm{H}^{+}$Pym, and the most stable $\mathrm{H}^{+} \mathrm{Pym}-\mathrm{N}_{2}$ isomers calculated at the B3LYP-D3/aug-cc-pVTZ level. Binding energies $\left(D_{0}\right)$ and bond lengths are given in $\mathrm{cm}^{-1}$ and $\AA$, respectively. Numbers in parentheses correspond to relative energies in $\mathrm{cm}^{-1}\left(E_{0}\right)$.

In both cases, $\mathrm{N}_{2}$ is pointing toward the positive charge, because the anisotropy of the charge-quadrupole and charge-induced dipole interactions favour a linear to a T-shaped approach for cation- $\mathrm{N}_{2}$ clusters. ${ }^{111,112}$ The $\pi$ attachment of $\mathrm{N}_{2}$ occurs without significant perturbation of the structural and vibrational parameters of the NH group $\left(\Delta r_{\mathrm{NH}}=-0.4 \mathrm{~m} \AA, \Delta \nu_{\mathrm{NH}}=4 \mathrm{~cm}^{-1}, \Delta I_{\mathrm{NH}}=\right.$ $-6 \mathrm{~km} \mathrm{~mol}^{-1}$ ), and the same is true for the $\mathrm{CH}$ groups (Fig. 2, 3 and Table 1). In contrast, the $\mathrm{N}-\mathrm{H}$ bond in the planar $\mathrm{H}^{+}$Pym- $\mathrm{N}_{2}(\mathrm{H})$ isomer is substantially modified by the linearly $\mathrm{H}$-bonded $\mathrm{N}_{2}$ ligand. The $\mathrm{N}-\mathrm{H}$ bond elongates with a concomitant decrease in the $\nu_{\mathrm{NH}}^{\mathrm{b}}$ frequency and a nearly fivefold increase in IR oscillator strength $\left(\Delta r_{\mathrm{NH}}=6.4 \mathrm{m \AA}, \Delta \nu_{\mathrm{NH}}=-119 \mathrm{~cm}^{-1}, \Delta I_{\mathrm{NH}}=\right.$ $\left.594 \mathrm{~km} \mathrm{~mol}^{-1}\right)$. The NBO analysis of the $\mathrm{NH} \cdots \mathrm{N}_{2}$ ionic $\mathrm{H}$-bond results in an orbital interaction energy of $E^{(2)}=36 \mathrm{~kJ} \mathrm{~mol}^{-1}$ between the $\sigma^{*}$ orbital of the $\mathrm{N}-\mathrm{H}$ bond and the lone pair of $\mathrm{N}_{2}$, which further supports its relatively high binding energy

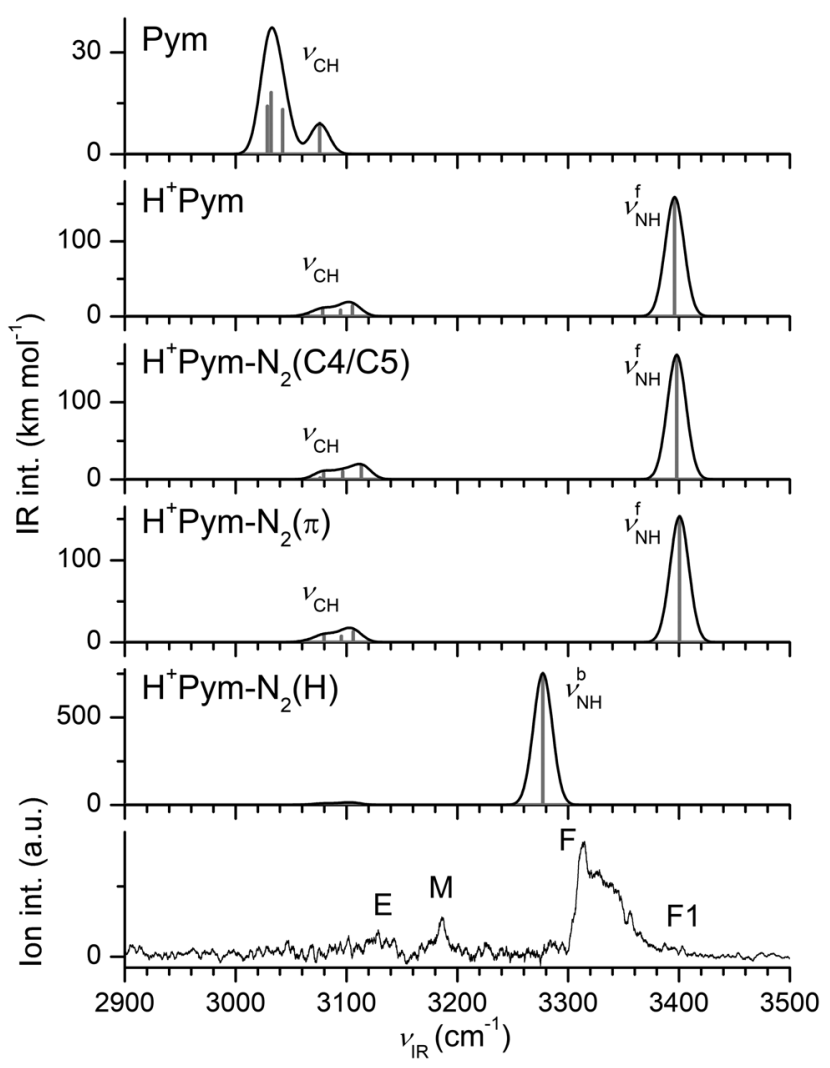

Fig. 3 Comparison of measured IRPD spectrum of $\mathrm{H}^{+} \mathrm{Pym}-\mathrm{N}_{2}$ with linear IR absorption spectra of Pym, $\mathrm{H}^{+} \mathrm{Pym}$, and various $\mathrm{H}^{+} \mathrm{Pym}-\mathrm{N}_{2}$ isomers obtained at the B3LYP-D3/aug-cc-pVTZ level (Table 1).

(Fig. S4 in the ESI $\dagger$ ). The NCI calculation also confirms the strong bonding $\left(-\rho^{*}=0.021\right.$ a.u., Fig. S5 in the ESI $\left.\dagger\right)$. Formation of the $\mathrm{NH} \cdots \mathrm{N}_{2}$ H-bond has almost no effect on the $\nu_{\mathrm{CH}}$ frequencies, because of the almost unchanged $\mathrm{C}-\mathrm{H}$ bond lengths $\left(\Delta \nu_{\mathrm{CH}} \leq\right.$ $1 \mathrm{~cm}^{-1}, \Delta r_{\mathrm{CH}} \leq 0.2 \mathrm{~mA}$, Fig. 2 and 3 ). In addition to the NH-bonded global and doubly degenerate $\pi$-bonded local minimum, we also explore the possibility of $\mathrm{N}_{2}$ binding to the weakly acidic $\mathrm{CH}$ groups. All attempts to locate such $\mathrm{CH}$-bonded minima with linear $\mathrm{CH} \cdots \mathrm{N}_{2}$ bonds fail. In the case of $\mathrm{C} 2 \mathrm{H}$ and $\mathrm{C6H}$, the structures converge to the $\mathrm{NH}$-bonded global minimum. For $\mathrm{C} 4 \mathrm{H}$ and $\mathrm{C} 5 \mathrm{H}$, optimization leads to a bifurcated $\mathrm{H}^{+}$Pym- $\mathrm{N}_{2}$ (C4/C5) dimer with $D_{0}=703 \mathrm{~cm}^{-1}$ (Fig. 2). This isomer is thus less stable than $\mathrm{H}^{+} \mathrm{Pym}-\mathrm{N}_{2}(\pi)$ but the IR spectra predicted for both local minima are quite similar in the investigated spectral range (Fig. 3). The corresponding C5/C6 structure converges to $\mathrm{H}^{+} \mathrm{Pym}-\mathrm{N}_{2}(\mathrm{H})$. We further consider two $\mathrm{N}_{2}$-bound isomers of a single C-protonated carbenium isomer, $\mathrm{H}^{+} \mathrm{Pym}(\mathrm{C} 5)-\mathrm{N}_{2}$ 
(Fig. S6 in the ESI $\dagger$ ). In these two isomers, $\mathrm{N}_{2}$ is either $\mathrm{H}$-bonded to one of the aliphatic $\mathrm{CH}_{2}$ bonds or $\pi$-bonded to the aromatic ring $\left(D_{0}=905\right.$ and $\left.1016 \mathrm{~cm}^{-1}\right)$. Their intense aliphatic $\nu_{\mathrm{CH}_{2}}$ modes are calculated below $2900 \mathrm{~cm}^{-1}$ (Fig. S7 in the ESI $\dagger$ ). Moreover, both isomers are highly unstable compared to $\mathrm{H}^{+}$Pym- $\mathrm{N}_{2}(\mathrm{H})$, with respect to both their relative energy $\left(E_{0}>\right.$ $17500 \mathrm{~cm}^{-1}$ ) and their intermolecular binding energy.

The IRPD spectrum measured for $\mathrm{H}^{+} \mathrm{Pym}-\mathrm{N}_{2}$ is compared in Fig. 3 to the linear IR spectra computed for $\mathrm{H}^{+} \mathrm{Pym}$ and its $\mathrm{H}^{+}$Pym $-\mathrm{N}_{2}$ isomers. The IRPD spectrum is dominated by an intense transition $\mathrm{F}$ peaking at $3313 \mathrm{~cm}^{-1}$, which is strongly blueshaded indicative of a proton donor stretch vibration. There are much weaker and relatively symmetric bands $\mathrm{M}, \mathrm{E}$, and $\mathrm{F} 1$ centred at 3186,3127 , and $3395 \mathrm{~cm}^{-1}$. Comparison of the IRPD spectrum with the simulated IR spectra in Fig. 3 suggests an assignment of the strong band $\mathrm{F}$ to $\nu_{\mathrm{NH}}^{\mathrm{b}}$ of the $\mathrm{H}$-bonded isomer predicted at $3277 \mathrm{~cm}^{-1}$ and the weak peak F1 to $\nu_{\mathrm{NH}}^{\mathrm{f}}$ of the $\pi$-bonded isomer calculated at $3400 \mathrm{~cm}^{-1}$, in line with both the positions and contours of the bands. Using the ratios of the observed integrated band intensities of bands $\mathrm{F}$ and $\mathrm{F} 1(\sim 20)$ and the predicted IR cross sections $(\sim 5)$, we arrive at a crude estimate of $1: 4$ for the relative abundance of the $\pi$ and $\mathrm{H}$ isomers of $\mathrm{H}^{+} \mathrm{Pym}-\mathrm{N}_{2}$, consistent with their computed binding energies. Assuming that the two isomers freeze out in their separate wells starting from room temperature and statistical weights of $2: 1$ for $\pi: \mathrm{H}$, one predicts a population of $8 \%$ for the $\pi$ isomer at thermal equilibrium, which is consistent with the crude experimental estimate. We take the measured $\nu_{\mathrm{NH}}^{\mathrm{f}}$ value of $\mathrm{H}^{+} \mathrm{Pym}-\mathrm{N}_{2}(\pi)$ to derive an accurate estimate for the experimental $\nu_{\mathrm{NH}}$ fundamental of bare $\mathrm{H}^{+}$Pym as $3391 \mathrm{~cm}^{-1}$ (using the predicted blueshift of $+4 \mathrm{~cm}^{-1}$ for $\pi$-bonded $\mathrm{N}_{2}$ ) and apply this value for evaluating frequency shifts upon $\mathrm{H}$-bonding. The calculations somewhat overestimate the redshift induced by H-bonding with $\mathrm{N}_{2}\left(-\Delta \nu_{\mathrm{NH}}^{\mathrm{b}}=\right.$ 119 vs. $\left.82 \mathrm{~cm}^{-1}\right)$. The broadish weak band $\mathrm{E}$ at $3127 \mathrm{~cm}^{-1}$ is assigned to the four aromatic $\nu_{\mathrm{CH}}$ modes predicted in the 3105-3065 $\mathrm{cm}^{-1}$ range for both isomers. Transition $\mathrm{M}$ at $3186 \mathrm{~cm}^{-1}$ can not be explained by any fundamental mode. However, the $\mathrm{NH}$ bending overtone $\left(2 \beta_{\mathrm{NH}}\right.$, strongly coupled to ring CC stretch modes) predicted at $3219 \mathrm{~cm}^{-1}$ for $\mathrm{H}^{+} \mathrm{Pym}-\mathrm{N}_{2}(\mathrm{H})$ can account for this transition (using a scaling factor of 0.98 for the fingerprint range). The $2 \beta_{\mathrm{NH}}$ overtone may acquire IR activity from the intense $\nu_{\mathrm{NH}}^{\mathrm{b}}$ fundamental of $\mathrm{H}^{+} \operatorname{Pym}-\mathrm{N}_{2}(\mathrm{H})$ via anharmonic coupling (Fermi resonance), which increases the splitting between both transitions, as is indicated by the comparison between the observed and computed difference (127 vs. $59 \mathrm{~cm}^{-1}$ ), because the harmonic treatment does not account for the coupling. Thus, we can fully explain the observed $\mathrm{H}^{+} \mathrm{Pym}-\mathrm{N}_{2}$ spectrum by the presence of the H-bonded (dominant) and $\pi$-bonded (minor) isomers of $\mathrm{N}$-protonated $\mathrm{H}^{+}$Pym- $\mathrm{N}_{2}$. In this scenario, we exclude a substantial population of the $\mathrm{CH}$-bonded isomer, which has a similar predicted IR spectrum as the $\pi$ isomer, just on the basis of its lower stability and lower statistical weight $(1: 2$ for $\mathrm{CH}$ to $\pi)$. On the other hand, we do not observe any transition below $2900 \mathrm{~cm}^{-1}$ indicative of strong transitions expected for aliphatic $\mathrm{CH}_{2}$ modes of the high-energy $\mathrm{N}_{2}$-tagged C-protonated isomers of $\mathrm{H}^{+} \mathrm{Pym}$ (Fig. S7 in the ESI $\dagger$ ) so that we conclude exclusive N-protonation in $\mathrm{H}^{+} \mathrm{Pym}$. For this reason, we do not consider carbenium isomers further.

\section{$3.3 \quad \mathbf{H}^{+}$Pym-W}

In general, the $\mathrm{H}^{+} \mathrm{Pym} \cdots \mathrm{W}$ interaction is much stronger than the $\mathrm{H}^{+}$Pym $\cdots \mathrm{N}_{2}$ interaction because of the additional dominating charge-dipole forces operating in the monohydrate. As a result, the structures optimized for all $\mathrm{H}^{+} \mathrm{Pym}-\mathrm{W}$ isomers displayed in Fig. 4 have a cation-dipole orientation with the $\mathrm{O}$ atom of W pointing toward the positive charge of N-protonated $\mathrm{H}^{+}$Pym. The binding energy of $\mathrm{W}$ in the linearly NH-bonded structure $\left(\theta_{\mathrm{OHN}}=179^{\circ}\right), \mathrm{H}^{+} \mathrm{Pym}-\mathrm{W}(\mathrm{H})$, is almost twice that of $\pi$-bonded $\mathrm{H}^{+} \mathrm{Pym}-\mathrm{W}(\pi), D_{0}=5854$ vs. $3081 \mathrm{~cm}^{-1}$, consistent with the shorter intermolecular bonds $\left(R_{\mathrm{NH} \cdots \mathrm{O}}=1.688 \AA, R_{\mathrm{O} \cdots \mathrm{N} 1 / \mathrm{C} 2} \sim 2.9-3.0 \AA\right)$. In the $\mathrm{H}^{+} \mathrm{Pym}-\mathrm{W}(\pi)$ local minimum, the $\mathrm{C}-\mathrm{H}$ and $\mathrm{N}-\mathrm{H}$ bond parameters remain mostly unchanged upon monohydration $\left(\Delta r_{\mathrm{CH} / \mathrm{NH}}<1.3 \mathrm{m \AA}\right)$, and the corresponding $\nu_{\mathrm{NH} / \mathrm{CH}}$ frequencies are little affected (e.g., $\Delta \nu_{\mathrm{NH}}^{\mathrm{f}}=+14 \mathrm{~cm}^{-1}$, Fig. 5). Similar to the $\mathrm{N}_{2}$ case, W strongly perturbs the $\mathrm{NH}$ group in the $\mathrm{H}^{+} \mathrm{Pym}-\mathrm{W}(\mathrm{H})$ global minimum through the formation of the linear $\mathrm{NH} \cdots \mathrm{O}$ ionic $\mathrm{H}$-bond, which is reflected in the elongated $\mathrm{N}-\mathrm{H}$ bond, along with a significant decrease in $\nu_{\mathrm{NH}}^{\mathrm{b}}$ and a roughly tenfold enhancement in the IR oscillator strength $\left(\Delta r_{\mathrm{NH}}=27 \mathrm{~m} \AA\right.$, $\left.\Delta \nu_{\mathrm{NH}}^{\mathrm{b}}=-463 \mathrm{~cm}^{-1}, \Delta I_{\mathrm{NH}}=1553 \mathrm{~km} \mathrm{~mol}^{-1}\right)$. The high PA of $\mathrm{W}$ $\left(691 \mathrm{~kJ} \mathrm{~mol}^{-1}\right)^{69}$ favours the formation of a strong $\mathrm{NH}$... O ionic H-bond by attracting a substantial amount of positive charge $(q=55 \mathrm{me})$ from $\mathrm{H}^{+}$Pym (Fig. S3 in the ESI $\left.\dagger\right)$. This charge transfer to $\mathrm{W}$ induces an elongation of the $\mathrm{O}-\mathrm{H}$ bonds $\left(\Delta r_{\mathrm{OH}}=1.9 \mathrm{m \AA}\right)$, along with frequency redshifts of $-\Delta \nu_{1 / 3}=16 / 30 \mathrm{~cm}^{-1}$ for the symmetric/antisymmetric $\mathrm{OH}$ stretch modes (Fig. 5). In addition, the polarization induced by the nearby positive charge leads to a substantial increase in the IR oscillator strength, which is more pronounced for $\nu_{1}$ than for $\nu_{3}$ (factor 11 and 2). The large $E^{(2)}$ energy ( $94 \mathrm{~kJ} \mathrm{~mol}^{-1}$ ) and high $\rho^{*}$ value $(-0.047$ a.u.) obtained from the NBO and NCI analyses further indicate the strength of this $\mathrm{NH} \cdots \mathrm{O}$ ionic H-bond (Fig. S4 and S5 in the ESI $\dagger$ ). Monohydration does not significantly affect the $\mathrm{C}-\mathrm{H}$ bond parameters of $\mathrm{H}^{+} \mathrm{Pym}-\mathrm{W}(\mathrm{H})\left(\Delta \nu_{\mathrm{CH}} \leq 2 \mathrm{~cm}^{-1}, \Delta I_{\mathrm{CH}} \leq 6 \mathrm{~km} \mathrm{~mol}^{-1}\right)$. In addition to the NH-bonded global and doubly degenerate $\pi$-bonded local minimum, we find two local $\mathrm{CH}$-bonded minima with $\mathrm{W}$ binding to the $\mathrm{CH}$ groups via bifurcated $\mathrm{CH} \cdots \mathrm{O} \mathrm{H}$-bonds (Fig. 4). These C4/C5 and C5/C6 local minima have similarly low binding energies as the $\pi$ isomer, $D_{0}=3027$ and $3346 \mathrm{~cm}^{-1}$, and are characterized by intense free NH stretch modes at 3403 and $3402 \mathrm{~cm}^{-1}$ (Fig. 5).

The IRPD spectrum recorded for $\mathrm{H}^{+} \mathrm{Pym}-\mathrm{W}$ is compared in Fig. 5 to the IR spectra computed for the all considered $\mathrm{H}^{+}$Pym-W dimers and the $\mathrm{H}^{+}$Pym and $\mathrm{W}$ monomers. At first glance, the IRPD spectrum lacks any signal for a free $\nu_{\mathrm{NH}}^{\mathrm{f}}$ band near $3400 \mathrm{~cm}^{-1}$, implying that only the $\mathrm{NH}$-bonded $\mathrm{H}^{+} \mathrm{Pym}-\mathrm{W}(\mathrm{H})$ global minimum contributes to the experimental spectrum, consistent with its much larger binding energy. From the integrated band intensities and the achieved signalto-noise ratio, the abundance of the $\pi$-bonded and $\mathrm{CH}$-bonded isomers is estimated to be well below $10 \%$. In general, the 


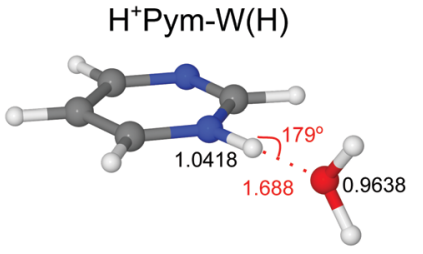

$D_{0}\left(E_{0}, G\right)=5854(0,0)$
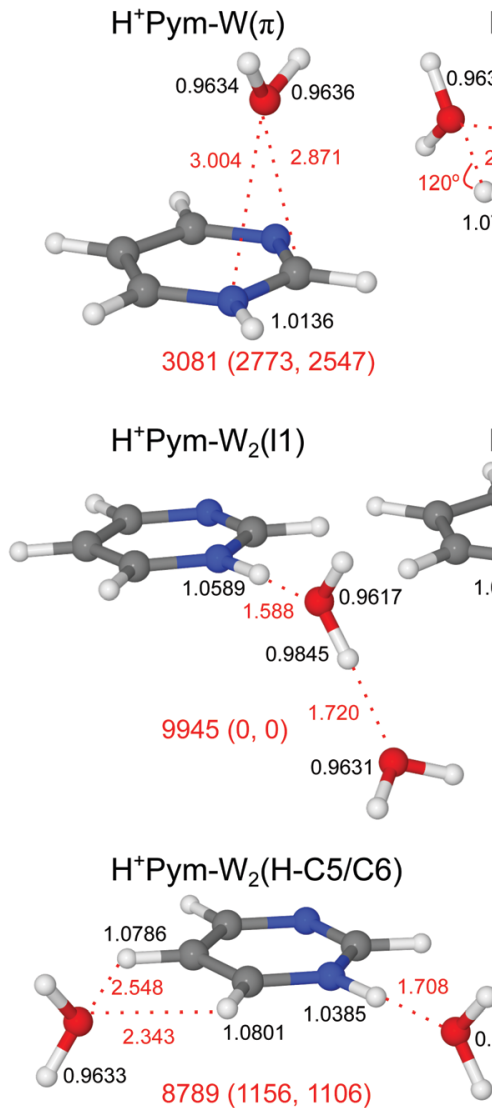

$8789(1156,1106)$

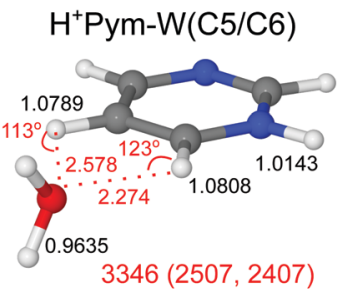

$\mathrm{H}^{+} \mathrm{Pym}-\mathrm{W}(\mathrm{C} 4 / \mathrm{C} 5)$

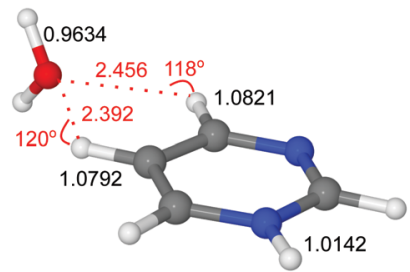

$3027(2826,2725)$

$\mathrm{H}^{+}$Pym- $\mathrm{W}_{2}(12)$
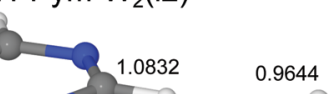

1.05250 .2 .506 1.625
0.9614
0.9770

$9746(199,542)$


1103
Fig. 4 Stable structures of various $\mathrm{H}^{+} \mathrm{Pym}-\mathrm{W}_{n}$ isomers with $n=1-2$ calculated at the B3LYP-D3/aug-cc-pVTZ level. Binding energies $\left(D_{0}\right)$ and bond lengths are given in $\mathrm{cm}^{-1}$ and $\AA$, respectively. Numbers in parentheses correspond to relative energies and free energies in $\mathrm{cm}^{-1}$ $\left(E_{0}, G\right)$. For comparison, the structures of $\mathrm{W}$ and $\mathrm{W}_{2}$ are also given.

overall appearance of the IRPD spectrum agrees well with that predicted for $\mathrm{H}^{+} \mathrm{Pym}-\mathrm{W}(\mathrm{H})$. Specifically, the two relatively sharp bands $\mathrm{A}$ and $\mathrm{B}$ at 3717 and $3633 \mathrm{~cm}^{-1}$ are readily assigned to the free $\mathrm{OH}$ stretch modes predicted at $\nu_{3}=3722$ and $\nu_{1}=3637 \mathrm{~cm}^{-1}$, respectively. The observed redshifts from bare $\mathrm{W}$ are consistent with the computed ones $\left(-\Delta \nu_{1 / 3}=24 / 39 v s\right.$. $16 / 30 \mathrm{~cm}^{-1}$ ), and also their observed relative intensities are close to the predicted ones. The strong and rather broad band $\mathrm{F}$ peaking at $2875 \mathrm{~cm}^{-1}$ is assigned to $\nu_{\mathrm{NH}}^{\mathrm{b}}$ of $\mathrm{H}^{+} \mathrm{Pym}-\mathrm{W}(\mathrm{H})$ predicted at $2933 \mathrm{~cm}^{-1}$, yielding a reasonable match between experimental and computed redshifts upon monohydration $\left(-\Delta \nu_{\mathrm{NH}}^{\mathrm{b}}=516\right.$ vs. $\left.463 \mathrm{~cm}^{-1}\right)$. Feature $\mathrm{F}$ is accompanied by satellite bands toward higher frequency. Such a vibrational band pattern is quite typical for strong $\mathrm{NH}$. . O ionic $\mathrm{H}$-bonds observed previously for a variety of monohydrated aromatic

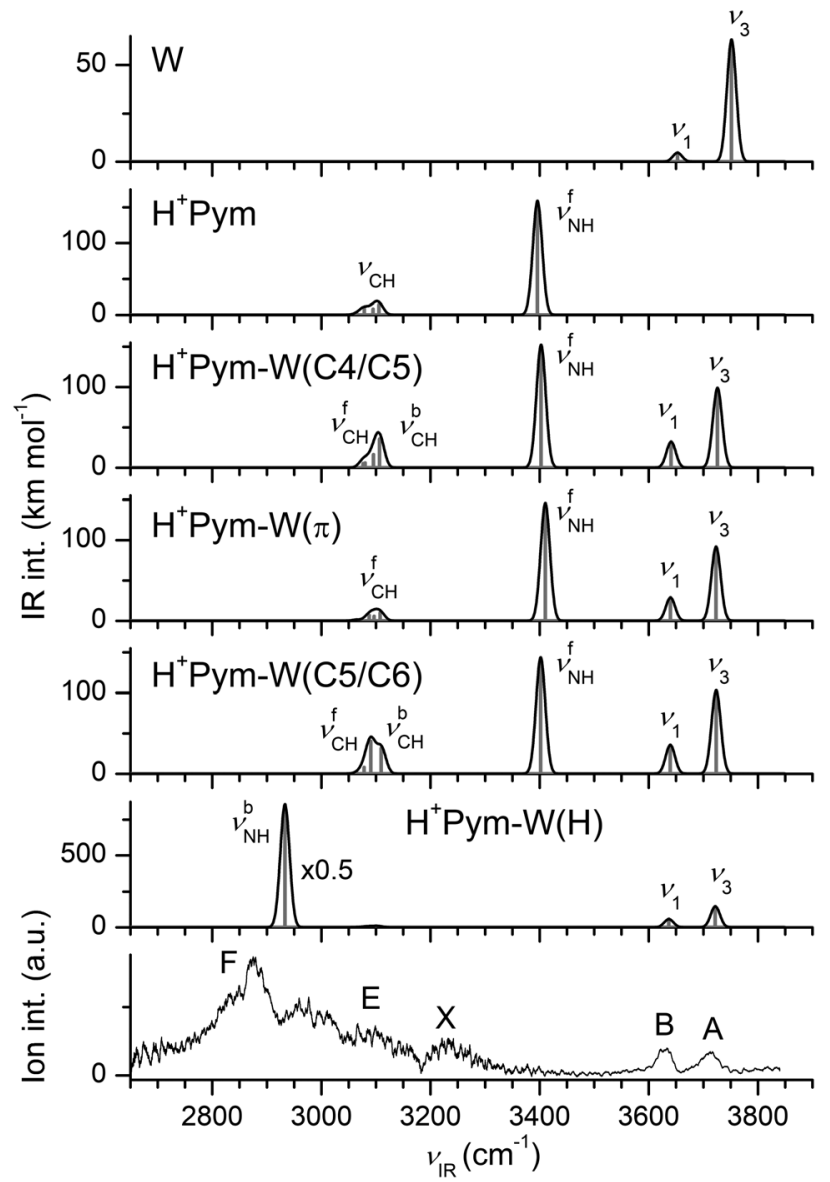

Fig. 5 Comparison of experimental IRPD spectrum of $\mathrm{H}^{+} \mathrm{Pym}-\mathrm{W}$ with linear IR spectra of $W, \mathrm{H}^{+}$Pym, and various $\mathrm{H}^{+} \mathrm{Pym}-\mathrm{W}$ isomers calculated at the B3LYP-D3/aug-cc-pVTZ level (Table 1).

cations. ${ }^{77,81-84}$ It arises from (near) resonant anharmonic interaction between the strongly IR active $\nu_{\mathrm{NH}}$ fundamental and the essentially dark $2 \beta_{\mathrm{NH}}$ overtone (and possibly $2 \beta_{\mathrm{OH}}$ of $\mathrm{W}$ ) along with weakly IR active overlapping aromatic $\nu_{\mathrm{CH}}$ fundamentals. It is difficult to identify the predicted $\nu_{\mathrm{CH}}$ modes near $3100 \mathrm{~cm}^{-1}$ experimentally, because they fall within the blue wing of band $\mathrm{F}$. The transition $\mathrm{X}$ at $3233 \mathrm{~cm}^{-1}$ is currently attributed to the water bend overtone predicted at $2 \beta_{\mathrm{OH}}=3220 \mathrm{~cm}^{-1}$ or to $2 \beta_{\mathrm{NH}}=3248 \mathrm{~cm}^{-1}$ (using a scaling factor of 0.98). In conclusion, the IRPD spectrum is assigned to a single isomer, namely the most stable H-bonded $\mathrm{H}^{+} \mathrm{Pym}-\mathrm{W}(\mathrm{H})$ global minimum. This single-photon IRPD spectrum is obtained in the $\mathrm{W}$ loss channel, although its computed binding energy is much higher than the IR photon energy $\left(D_{0}=5954 \mathrm{~cm}^{-1}\right.$, $\left.\nu_{\mathrm{IR}}<3800 \mathrm{~cm}^{-1}\right)$. Hence, we do not observe IRPD from the ground vibrational state but of ions with substantial internal energy ( $E_{\text {int }}>2000-3000 \mathrm{~cm}^{-1}$ ), explaining the observed larger width of the transitions as compared to the $\mathrm{H}^{+} \mathrm{Pym}-\mathrm{N}_{2}$ spectrum for which no internal energy is required for IRPD to be observed $\left(D_{0}=1530 \mathrm{~cm}^{-1}\right.$ is actually an upper limit for $\left.E_{\mathrm{int}}\right)$.

\section{4 $\mathbf{H}^{+}$Pym-W}

The IRMPD spectra of $\mathrm{H}^{+} \mathrm{Pym}-\mathrm{W}_{n}$ in Fig. 1 reveal substantial incremental redshifts of band $\mathrm{F}$ assigned to $\nu_{\mathrm{NH}}^{\mathrm{b}}$ as $n$ increases 
from 1 to 4 , demonstrating that the $\mathrm{W}$ ligands successively attach to the $\mathrm{NH}$ binding site of $\mathrm{H}^{+}$Pym by forming a $\mathrm{W}_{n}$ solvent network. Indeed, in the most stable structure of $\mathrm{H}^{+} \mathrm{Pym}-\mathrm{W}_{2}(\mathrm{l1})$ shown in Fig. 4, a linear $\mathrm{H}$-bonded $\mathrm{W}_{2}$ dimer is attached to $\mathrm{H}^{+}$Pym via a $\mathrm{NH}$.. O ionic $\mathrm{H}$-bond, with a total binding energy of $D_{0}=9945 \mathrm{~cm}^{-1}$. The formation of such a H-bonded solvent network is strongly cooperative because of nonadditive induction forces, so that both the $\mathrm{NH} \cdots \mathrm{O}$ and $\mathrm{OH} \cdots \mathrm{O} \mathrm{H}$-bonds in $\mathrm{H}^{+} \mathrm{Pym}-\mathrm{W}_{2}$ are much stronger and shorter than in the respective $\mathrm{H}^{+}$Pym-W and $\mathrm{W}_{2}$ dimer subunits $\left(R_{\mathrm{NH} \cdots \mathrm{O}}=1.588 v s\right.$. $1.688 \AA, R_{\mathrm{OH} \cdots \mathrm{O}}=1.720$ vs. $1.947 \AA$ ). This effect is also visible in the binding energies, because the total binding energy of $D_{0}=9945 \mathrm{~cm}^{-1}$ is $43 \%$ larger than the sum of the two dimer units $\left(D_{0}=6957 \mathrm{~cm}^{-1}\right)$. Similarly, the $E^{(2)}$ and $-\rho^{*}$ values for the two H-bonds in the trimer (141 and $74 \mathrm{~kJ} \mathrm{~mol}^{-1}, 0.061$ and 0.042 a.u.) are larger than those in the dimers (94 and $32 \mathrm{~kJ} \mathrm{~mol}^{-1}, 0.047$ and 0.026 a.u., Fig. S4 and S5 in the ESI $\left.\dagger\right)$. The stronger $\mathrm{NH} \cdots \mathrm{O}$ bond in the $n=2$ cluster is also rationalized by the higher proton affinity of $\mathrm{W}_{2}$ as compared to $\mathrm{W}$ (808 vs. $\left.691 \mathrm{~kJ} \mathrm{~mol}^{-1}\right),{ }^{69,70}$ leading to a larger charge transfer from $\mathrm{H}^{+}$Pym to the solvent (79 vs. 55 me, Fig. $\mathrm{S} 3$ in the ESI $\dagger$ ). Due to the stronger $\mathrm{NH} \cdots \mathrm{O} \mathrm{H}$-bond in the $n=2$ cluster, the $\mathrm{N}-\mathrm{H}$ bond is more strongly activated by dihydration than by monohydration $\left(\Delta r_{\mathrm{NH}}=44\right.$ vs. $\left.27 \mathrm{~mA}\right)$, leading to a larger redshift in $\nu_{\mathrm{NH}}^{\mathrm{b}}\left(-\Delta \nu_{\mathrm{NH}}^{\mathrm{b}}=738\right.$ vs. $\left.463 \mathrm{~cm}^{-1}\right)$ and IR enhancement $\left(I_{\mathrm{NH}}=2701\right.$ vs. $\left.1712 \mathrm{~km} \mathrm{~mol}^{-1}\right)$ as shown in Fig. 6. The $\mathrm{O}-\mathrm{H}$ bonds of the terminal $\mathrm{W}$ in $\mathrm{H}^{+} \mathrm{Pym}-\mathrm{W}_{2}$ are less elongated than in $\mathrm{H}^{+} \mathrm{Pym}-\mathrm{W}\left(\Delta r_{\mathrm{OH}}=1.2\right.$ vs. $\left.1.9 \mathrm{m \AA}\right)$, because they are farther away from the positive charge, thus producing smaller redshifts in $\nu_{\mathrm{OH}}\left(-\Delta \nu_{1 / 3}=8 / 18 v s\right.$. $\left.16 / 30 \mathrm{~cm}^{-1}\right)$. The free $\mathrm{O}-\mathrm{H}$ bond of the proton donor $\mathrm{W}$ ligand is much shorter than the bonded one (by $23 \mathrm{~mA}$ ), leading to a much higher frequency for the free $\mathrm{OH}$ stretch $\left(\nu_{\mathrm{f}}=3706 \mathrm{~cm}^{-1}\right.$, occurring between $\nu_{1}$ and $\left.\nu_{3}\right)$ than the bonded $\mathrm{OH}$ stretch $\left(\nu_{\mathrm{OH}}^{\mathrm{b}}=3275 \mathrm{~cm}^{-1}\right)$. The latter one is largely redshifted from that of bare $\mathrm{W}_{2}\left(\nu_{\mathrm{OH}}^{\mathrm{b}}=3601 \mathrm{~cm}^{-1}\right)$ due to the massive threebody effects induced by the nearby $\mathrm{H}^{+}$Pym cation (Fig. 6). Similar to $n=1$, the parameters of the $\mathrm{C}-\mathrm{H}$ bonds including $\nu_{\mathrm{CH}}$ are hardly affected for $n=2$ upon hydration of the $\mathrm{NH}$ group of $\mathrm{H}^{+} \mathrm{Pym}$ (Fig. 4 and Table 1 ).

We consider in Fig. 4 two further less stable local minima. Like in the 11 global minimum, in the 12 isomer a $\mathrm{H}$-bonded $\mathrm{W}_{2}$ dimer is attached to the $\mathrm{NH}$ group of $\mathrm{H}^{+} \mathrm{Pym}$. This isomer is further stabilized by a weak $\mathrm{CH}$. O contact of the terminal $\mathrm{W}$ ligand to the $\mathrm{C} 2 \mathrm{H}$ group in ortho position of the $\mathrm{NH}$ group. However, to make this contact, the first $\mathrm{W}$ ligand has to rotate into the $\mathrm{H}^{+}$Pym plane leading to a weaker and longer $\mathrm{NH} \cdots \mathrm{O}$ $\mathrm{H}$-bond. In addition, the $\mathrm{W} \cdot \mathrm{W}$ bond is less linear and weaker due to this additional steric constraint. The weaker $\mathrm{OH} \cdots \mathrm{O}$ and $\mathrm{NH}$. . O H-bond strengths are also indicated by the NBO and NCI indices (Fig. S4 and S5 in the ESI†). Both of these modifications cost energy so that the 12 isomer is in total $\Delta E_{0}=199 \mathrm{~cm}^{-1}$ less stable than the global minimum despite its additional $\mathrm{CH} \cdots \mathrm{O} \mathrm{H}$-bond. As a result, the spectral signatures of the 12 isomer are less redshifted $\nu_{\mathrm{NH}}^{\mathrm{b}}$ and $\nu_{\mathrm{OH}}^{\mathrm{b}}$ transitions than for I1, a weakly appearing $\nu_{\mathrm{CH}}^{\mathrm{b}}$ band, and merging of $\nu_{\mathrm{f}}$ and $\nu_{3}$ into a single band (Fig. 6). The third and much less stable

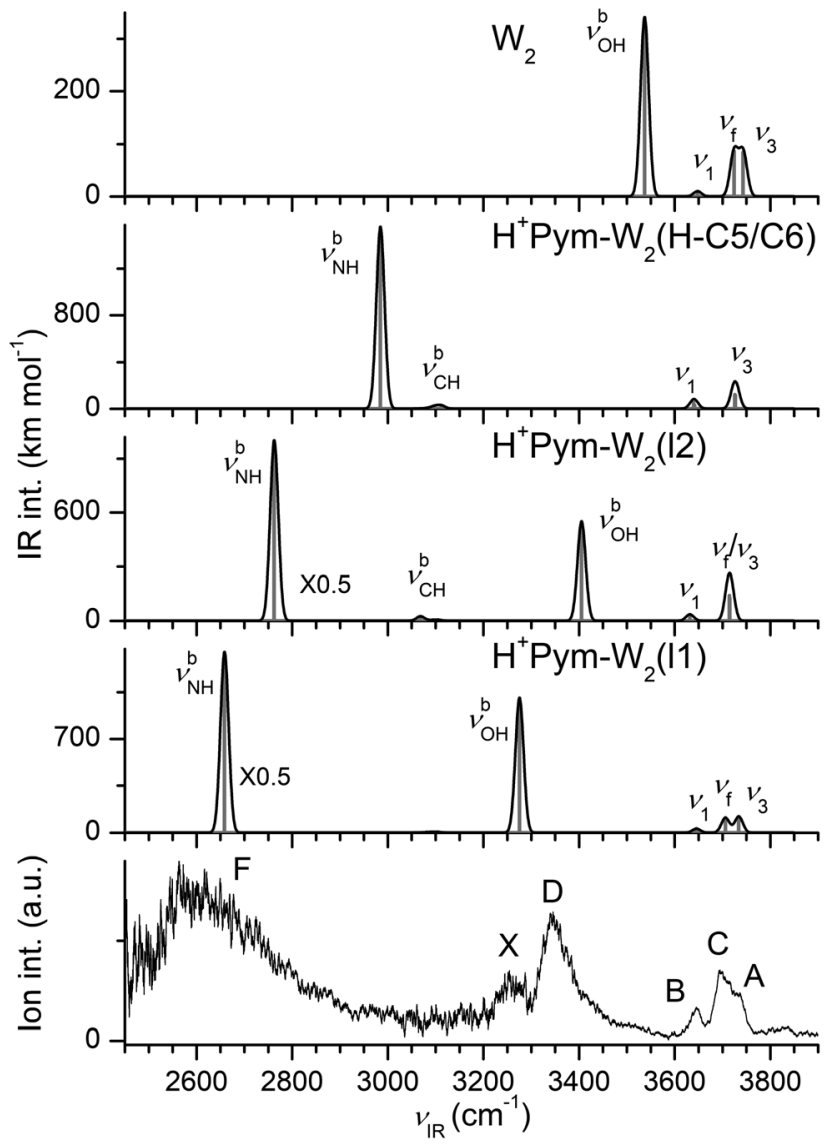

Fig. 6 Comparison of experimental IRPD spectrum of $\mathrm{H}^{+} \mathrm{Pym}-\mathrm{W}_{2}$ with linear IR spectra of $W_{2}$ and various $\mathrm{H}^{+} \mathrm{Pym}-\mathrm{W}_{2}$ isomers calculated at the B3LYP-D3/aug-cc-pVTZ level (Table 1).

$\mathrm{H}^{+}$Pym- $\mathrm{W}_{2}$ isomer denoted $\mathrm{H}-\mathrm{C} 5 / \mathrm{C} 6$ has two $\mathrm{W}$ ligands separately attached to the $\mathrm{NH}$ group (linear) and $\mathrm{C} 5 \mathrm{H} / \mathrm{C} 6 \mathrm{H}$ groups (bifurcated). The H-bonds are slightly weaker than those in the respective $\mathrm{H}^{+}$Pym-W dimers, because of the small noncooperative threebody induction forces typical for interior ion solvation. These effects are also visible in the NBO and NCI indices of these $\mathrm{H}$-bonds (Fig. S4 and S5 in the ESI $\dagger$ ). As a result, the total binding energy of this isomer, $D_{0}=8789 \mathrm{~cm}^{-1}$, is $4.5 \%$ smaller than the sum of the two dimer binding energies $\left(D_{0}=9200 \mathrm{~cm}^{-1}\right)$, and thus much smaller than that of the 11 global minimum (by $\Delta E_{0}=1156 \mathrm{~cm}^{-1}$ ). The spectral signatures of this isomer are a $\nu_{\mathrm{NH}}^{\mathrm{b}}$ band slightly blueshifted from that of $\mathrm{H}^{+} \mathrm{Pym}-\mathrm{W}(\mathrm{H})$, a weakly appearing $\nu_{\mathrm{CH}}^{\mathrm{b}}$ band, and the lack of any $\nu_{\mathrm{OH}}^{\mathrm{b}} / \nu_{\mathrm{f}}$ transitions (Fig. 6).

Addition of the second $\mathrm{W}$ ligand to $\mathrm{H}^{+} \mathrm{Pym}-\mathrm{W}$ leads to several new features occurring in the IRPD spectrum (Fig. 1), such as bands $\mathrm{C}$ and $\mathrm{D}$. In addition, band $\mathrm{F}$ exhibits a large redshift. Both observations are consistent with the formation of the $\mathrm{H}^{+} \mathrm{Pym}-\mathrm{W}_{2}(\mathrm{l} 1)$ global minimum shown in Fig. 4. Its predicted IR spectrum is compared in Fig. 6 to the observed IRPD spectrum, along with the spectra computed for the two less stable $\mathrm{H}^{+} \mathrm{Pym}-\mathrm{W}_{2}$ isomers and bare $\mathrm{W}_{2}$. At first glance, the IRPD spectrum of $\mathrm{H}^{+} \mathrm{Pym}-\mathrm{W}_{2}$ shows very good agreement with the spectrum computed for the 11 isomer, suggesting the presence of a single isomer, namely the most stable global 
minimum. The broad blueshaded band $\mathrm{F}$ peaking at $2605 \mathrm{~cm}^{-1}$ is assigned to the $\nu_{\mathrm{NH}}^{\mathrm{b}}$ proton donor stretch predicted at $2658 \mathrm{~cm}^{-1}$, implying good agreement between observed and computed redshifts $\left(-\nu_{\mathrm{NH}}^{\mathrm{b}}=786 v s .738 \mathrm{~cm}^{-1}\right)$. Bands A and B are assigned to $\nu_{3}\left(3734 \mathrm{~cm}^{-1}\right)$ and $\nu_{1}\left(3645 \mathrm{~cm}^{-1}\right)$ of the terminal $\mathrm{W}$ acceptor ligand. The observed blueshifts with respect to the $n=1$ cluster agree well with the prediction $\left(\Delta \nu_{3 / 1}=13 / 12\right.$ vs. $\left.12 / 8 \mathrm{~cm}^{-1}\right)$. The two new bands $\mathrm{C}$ and $\mathrm{D}$ at 3698 and $3340 \mathrm{~cm}^{-1}$ are attributed to $\nu_{\mathrm{f}}$ and $\nu_{\mathrm{OH}}^{\mathrm{b}}$ of the $\mathrm{H}$-bonded $\mathrm{W}$ donor ligand computed as 3706 and $3275 \mathrm{~cm}^{-1}$, respectively. Similar to $n=1$, the remaining band $\mathrm{X}$ at $3250 \mathrm{~cm}^{-1}$ is tentatively attributed to the water bending overtone $\left(2 \beta_{\mathrm{OH}}\right)$ or to $2 \beta_{\mathrm{NH}}$, which are not included in the harmonic simulations (Table 1 ). We may exclude a significant population of the two less stable $\mathrm{H}^{+} \mathrm{Pym}-\mathrm{W}_{2}$ isomers, because their predicted intense $\nu_{\mathrm{NH}}^{\mathrm{b}}$ and $\nu_{\mathrm{OH}}^{\mathrm{b}}$ bands do not show up as pronounced separate peaks (with sharp P-branch heads and blueshaded shoulders) in the IRPD spectrum. The binding energy of the terminal $\mathrm{W}$ ligand in $\mathrm{H}^{+} \mathrm{Pym}-\mathrm{W}_{2}(\mathrm{l} 1)$ is calculated as $4091 \mathrm{~cm}^{-1}$, implying that single-photon IRPD for $\mathrm{W}$ loss should be possible for ions with little vibrational excitation. Thus, the IRPD spectrum of the $n=2$ cluster is obtained from ions with lower effective temperature, leading to narrower transitions than for $n=1$ (Fig. 1 and Table 1).

\section{5 $\mathbf{H}^{+}$Pym-W}

We consider in Fig. 7 four conceivable low-energy isomers of $\mathrm{H}^{+} \mathrm{Pym}-\mathrm{W}_{3}$, which are derived from the $\mathrm{H}^{+} \mathrm{Pym}-\mathrm{W}_{2}(\mathrm{l} 1 / \mathrm{l} 2)$ isomers by addition of $\mathrm{W}$ to either the bridging or terminal $\mathrm{W}$ ligand. This procedure yields two branched and two linear isomers within $\Delta E_{0}=275 \mathrm{~cm}^{-1}$, with $D_{0}=13454$ (b1) > 13296 (b2) > 13213 (l1) > $13179 \mathrm{~cm}^{-1}$ (12), respectively. Based on their small energy difference at $T=0 \mathrm{~K}$, all four may be populated in the supersonic expansion. However, the b1 and 11 isomers are entropically strongly favoured at
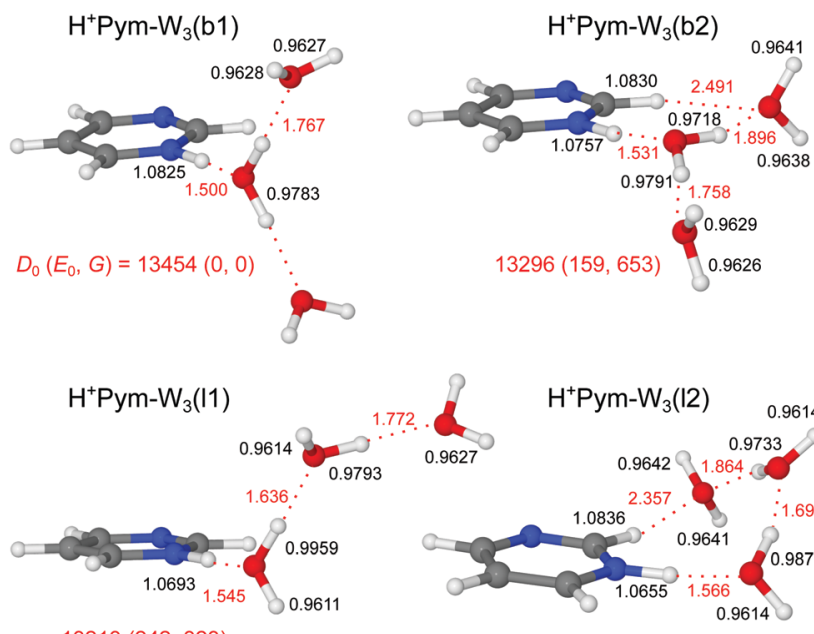

$13213(242,323)$

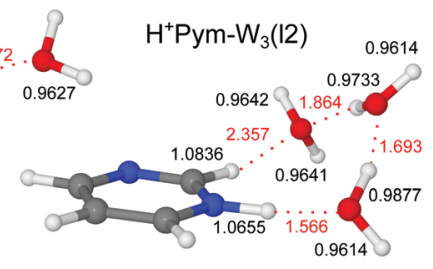

$13179(275,1035)$

Fig. 7 Stable structures of various $\mathrm{H}^{+} \mathrm{Pym}-\mathrm{W}_{3}$ isomers calculated at the B3LYP-D3/aug-cc-pVTZ level. Binding energies $\left(D_{0}\right)$ and bond lengths are given in $\mathrm{cm}^{-1}$ and $\AA$, respectively. Numbers in parentheses correspond to relative energies and free energies in $\mathrm{cm}^{-1}\left(E_{0}, G\right)$. elevated temperature, because they are more flexible due to the lack of the $\mathrm{CH} \cdots \mathrm{O}$ contact.

The $\mathrm{H}^{+}$Pym- $\mathrm{W}_{3}(\mathrm{~b} 1)$ global minimum with $C_{\mathrm{s}}$ symmetry has two equivalent terminal $\mathrm{W}$ ligands. The increased proton affinity of $\mathrm{W}_{3}\left(\mathrm{PA}=862 \mathrm{~kJ} \mathrm{~mol}^{-1}\right)$ improves the binding of the solvent cluster to the acidic $\mathrm{NH}$ group of $\mathrm{H}^{+} \mathrm{Pym}$, which further activates its $\mathrm{N}-\mathrm{H}$ bond $\left(\Delta r_{\mathrm{NH}}=68 \mathrm{m \AA}, \Delta \nu_{\mathrm{NH}}^{\mathrm{b}}=\right.$ $-1084 \mathrm{~cm}^{-1}, I_{\mathrm{NH}}=3640 \mathrm{~km} \mathrm{~mol}{ }^{-1}$, Fig. 8). The stronger H-bond $\left(R_{\mathrm{NH} \cdots \mathrm{O}}=1.500 \AA\right)$ implies an increasing charge transfer from $\mathrm{H}^{+}$Pym to $\mathrm{W}_{3}(111 \mathrm{me})$, a larger $E^{(2)}$ energy $\left(201 \mathrm{~kJ} \mathrm{~mol}^{-1}\right)$ and a higher $\rho^{*}$ value $(-0.077$ a.u.) (Fig. S3-S5 in the ESI $\dagger$ ). The intermolecular $\mathrm{OH} \cdots \mathrm{O} \mathrm{H}$-bonds within the $\mathrm{W}_{3}$ network are slightly weaker than in $\mathrm{H}^{+} \mathrm{Pym}-\mathrm{W}_{2}$ (1.767vs. $1.720 \AA$ A) because of increased charge delocalization in the larger hydrate. As a result, all $\mathrm{O}-\mathrm{H}$ bonds become slightly shorter $\left(\Delta r_{\mathrm{OH}}=-6.2\right.$ and $-0.3 \mathrm{m \AA}$ for bonded and free $\mathrm{O}-\mathrm{H}$ bonds), resulting in blueshifts of both the bound and the free $\mathrm{OH}$ stretch modes $\left(\Delta \nu_{\mathrm{OH}}^{\mathrm{b}}=122 / 84 \mathrm{~cm}^{-1}, \Delta \nu_{1 / 3}=4 / 5 \mathrm{~cm}^{-1}\right)$.

In the $\mathrm{H}^{+} \mathrm{Pym}-\mathrm{W}_{3}(\mathrm{l} 1)$ local minimum, a linear $\mathrm{W}_{3}$ chain is attached to the acidic $\mathrm{NH}$ group of $\mathrm{H}^{+} \mathrm{Pym}$. The $\mathrm{NH} \cdots \mathrm{O}$ ionic $\mathrm{H}$-bond is slightly weaker than in $\mathrm{H}^{+} \mathrm{Pym}-\mathrm{W}_{3}(\mathrm{~b} 1)$, as evidenced from longer values for $R_{\mathrm{NH} \cdots \mathrm{O}}(1.545 \AA)$, and smaller $E^{(2)}$ (169 kJ mol$\left.{ }^{-1}\right), \Delta q$ (96 me), $\rho^{*}\left(-0.069\right.$ a.u.), $\Delta r_{\mathrm{NH}}(55 \mathrm{~mA})$, $\Delta \nu_{\mathrm{NH}}^{\mathrm{b}}\left(-899 \mathrm{~cm}^{-1}\right)$, and $I_{\mathrm{NH}}\left(3286 \mathrm{~km} \mathrm{~mol}^{-1}\right)$. The two

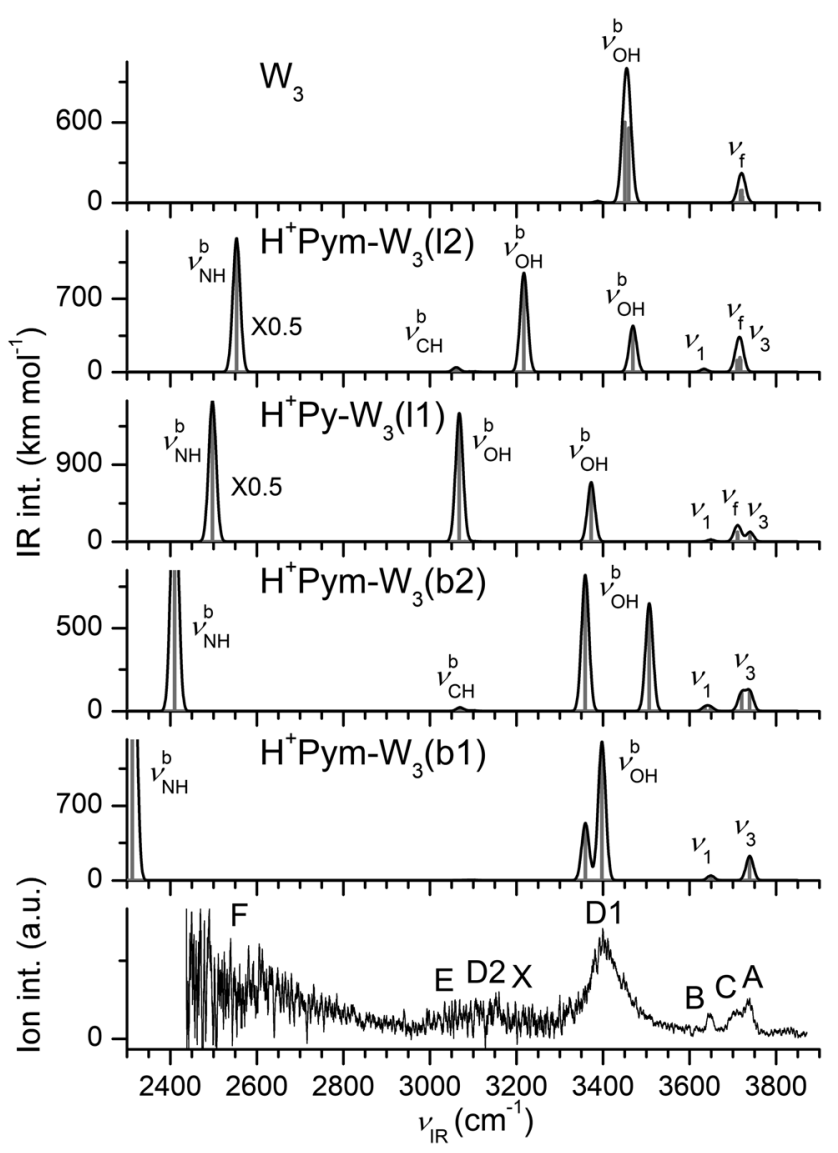

Fig. 8 Comparison of experimental IRPD spectrum of $\mathrm{H}^{+} \mathrm{Pym}-\mathrm{W}_{3}$ with linear IR spectra of $W_{3}$ and various $\mathrm{H}^{+} \mathrm{Pym}-\mathrm{W}_{3}$ clusters calculated at the B3LYP-D3/aug-cc-pVTZ level (Table 1). 
nonequivalent $\mathrm{OH} \cdots \mathrm{O}$ H-bonds $\left(R_{\mathrm{OH} \cdots \mathrm{O}}=1.636\right.$ and $\left.1.772 \AA\right)$ give rise to rather different $\nu_{\mathrm{OH}}^{\mathrm{b}}$ frequencies of 3068 and $3373 \mathrm{~cm}^{-1}$, while their corresponding $\nu_{\mathrm{f}}$ modes are rather similar ( 3712 and $3710 \mathrm{~cm}^{-1}$ ). The terminal $\mathrm{W}$ ligand is far away from the positive charge, and thus its perturbation from bare $\mathrm{W}$ is small $\left(\Delta r_{\mathrm{OH}}=0.8 \mathrm{m \AA}, \Delta \nu_{1 / 3}=-4 /-12 \mathrm{~cm}^{-1}\right)$.

The b2 and 12 isomers of $\mathrm{H}^{+} \mathrm{Pym}-\mathrm{W}_{3}$ are characterized by a weak $\mathrm{CH} \cdots \mathrm{O}$ contact. However, like for the 12 isomer of the $n=2$ clusters, this additional $\mathrm{H}$-bond is accompanied by steric strain in the other $\mathrm{H}$-bonds leading as a net effect to only slightly higher relative energies $\left(E_{0}=159\right.$ and $\left.275 \mathrm{~cm}^{-1}\right)$ but substantially larger relative free energies at room temperature $\left(G=653\right.$ and $\left.1035 \mathrm{~cm}^{-1}\right)$.

The IRPD spectrum of $\mathrm{H}^{+} \mathrm{Pym}-\mathrm{W}_{3}$ is compared in Fig. 8 to the IR spectra predicted for the linear and branched isomers, along with the spectrum computed for cyclic $\mathrm{W}_{3}$. At first glance, it is obvious that the IRPD spectrum mostly arises from the branched $\mathrm{H}^{+} \mathrm{Pym}-\mathrm{W}_{3}(\mathrm{~b} 1)$ global minimum. The bands $\mathrm{A}$ and $\mathrm{B}$ at 3736 and $3647 \mathrm{~cm}^{-1}$ are attributed to the free $\nu_{3}$ and $\nu_{1}$ modes predicted at 3739 and $3649 \mathrm{~cm}^{-1}$. The observed incremental blueshifts from the $n=2$ cluster agree well with the prediction $\left(\Delta \nu_{3 / 1}=6 / 2\right.$ vs. $\left.5 / 4 \mathrm{~cm}^{-1}\right)$. The corresponding symmetric and antisymmetric bound $\nu_{\mathrm{OH}}^{\mathrm{b}}$ modes predicted at 3359 and $3397 \mathrm{~cm}^{-1}$ occur as a single blueshaded band D1 peaking at $3399 \mathrm{~cm}^{-1}$. The b2 and 12 isomers can be excluded as major carriers of the experimental spectrum, in line with their high free energies. The spectrum predicted for $\mathrm{b} 2$ has two roughly equally intense $\nu_{\mathrm{OH}}^{\mathrm{b}}$ modes at 3507 and $3359 \mathrm{~cm}^{-1}$ (with a large splitting of $148 \mathrm{~cm}^{-1}$ ), and such a pattern is not observed experimentally. A similar argument applies to isomer 12. Band $\mathrm{C}$ at $3709 \mathrm{~cm}^{-1}$ cannot be explained by b1 and is thus considered as a unique spectroscopic signature of the 11 local minimum, because it is the only remaining structure with uncoupled free $\mathrm{OH}$ stretch oscillators (predicted at 3710 and $\left.3712 \mathrm{~cm}^{-1}\right)$. Its corresponding bound $\mathrm{OH}$ stretch modes predicted at 3068 and $3373 \mathrm{~cm}^{-1}$ appear as band D2 centred at $3152 \mathrm{~cm}^{-1}$ and overlap with band D1 at $3399 \mathrm{~cm}^{-1}$, respectively. Similarly, its predicted $\nu_{1 / 3}$ bands coincide with those of the $\mathrm{b} 1$ isomer resulting in bands $\mathrm{A}$ and $\mathrm{B}$. The signal near $\sim 3100 \mathrm{~cm}^{-1}$ (E) and $3228 \mathrm{~cm}^{-1}$ (X) is attributed to $\nu_{\mathrm{CH}}$ and $2 \beta_{\mathrm{OH}}$ modes of both the linear and branched isomers. At the red end of the experimental spectrum, the signal rises more or less monotonically toward $2450 \mathrm{~cm}^{-1}$ (band F), which is the end of the scanning range of the IR laser. Signal in this spectral range is attributed to the blue wing of the $\nu_{\mathrm{NH}}^{\mathrm{b}}$ modes of $\mathrm{H}^{+}$Pym- $-\mathrm{W}_{3}(\mathrm{~b} 1)$ and $\mathrm{H}^{+} \mathrm{Pym}-\mathrm{W}_{3}(\mathrm{l} 1)$ predicted at 2312 and $2497 \mathrm{~cm}^{-1}$, respectively. Considering the relative intensities of bands D2 and D1, as well as bands A-C, along with the calculated oscillator strengths, we can clearly conclude a much higher abundance of the b1 global minimum compared to the 11 local minimum, with a crudely estimated population ratio of $\sim 5: 1$.

\section{6 $\mathbf{H}^{+}$Pym-W}

Four low-energy computed minima of $\mathrm{H}^{+} \mathrm{Pym}-\mathrm{W}_{4}$ are considered in Fig. 9 (structures) and Fig. 10 (IR spectra), all of which are within $E_{0}<205 \mathrm{~cm}^{-1}$. In contrast to the $n=1-3$ isomers,
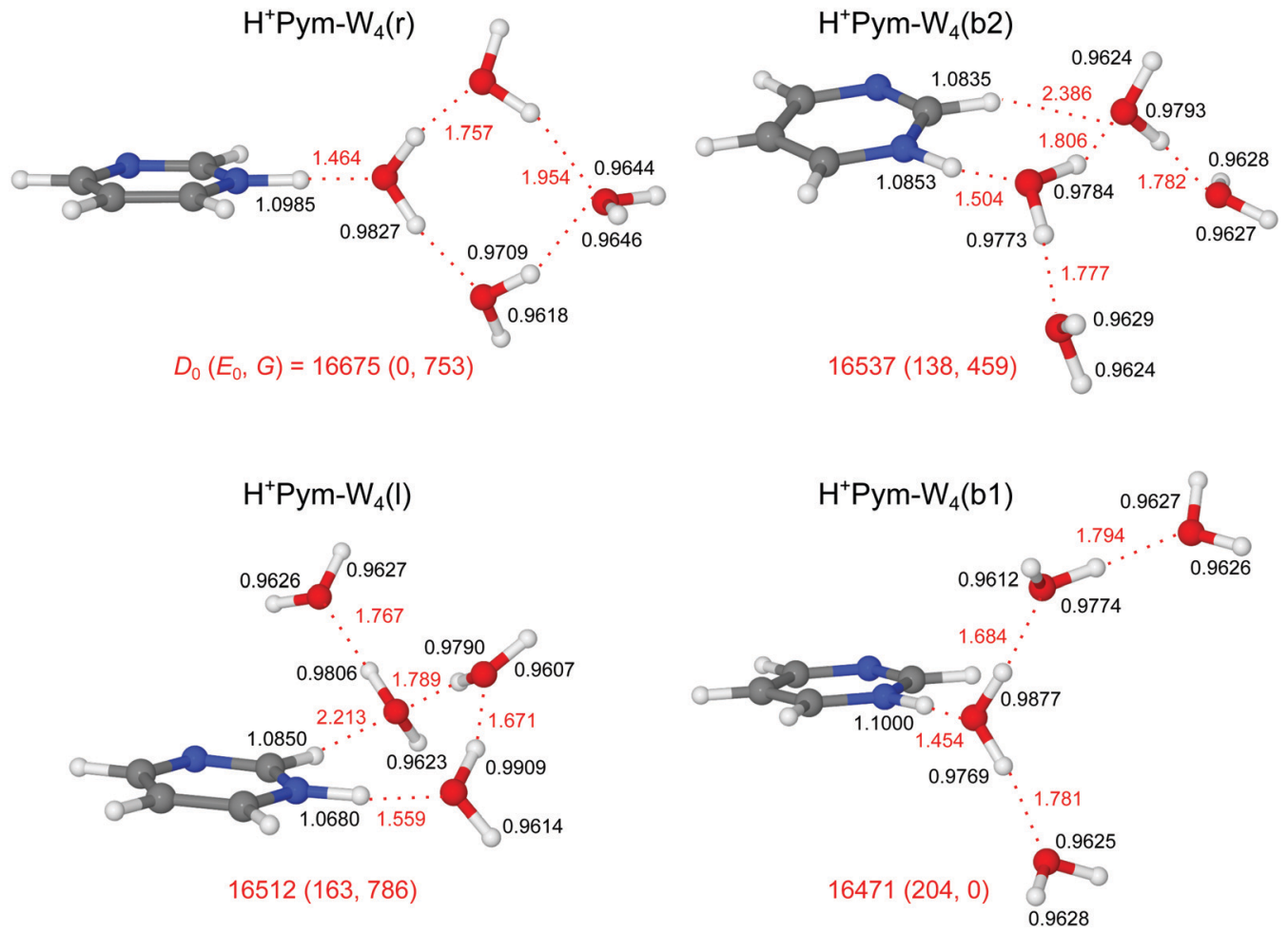

Fig. 9 Stable structures of various $\mathrm{H}^{+}$Pym- $\mathrm{W}_{4}$ isomers calculated at the B3LYP-D3/aug-cc-pVTZ level. Binding energies $\left(D_{0}\right)$ and bond lengths are given in $\mathrm{cm}^{-1}$ and $\AA$, respectively. Numbers in parentheses correspond to relative energies and free energies in $\mathrm{cm}^{-1}\left(E_{0}, G\right)$. 


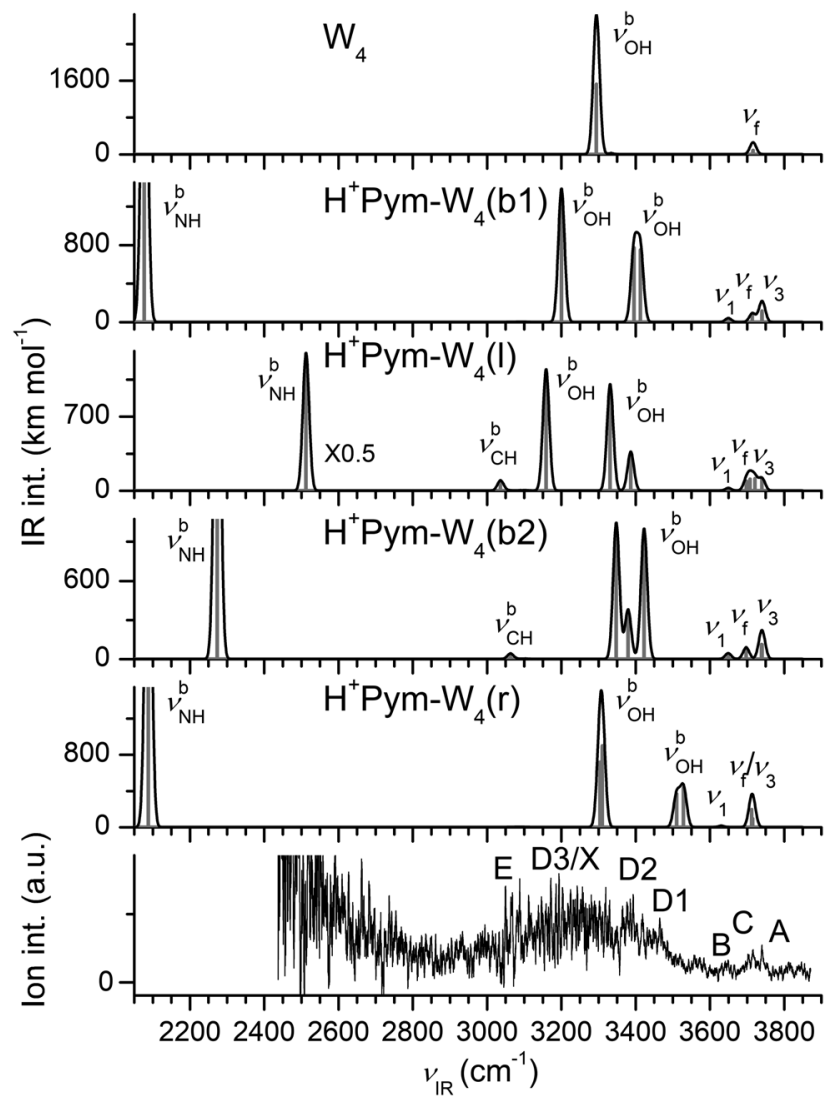

Fig. 10 Comparison of experimental IRPD spectrum of $\mathrm{H}^{+} \mathrm{Pym}-\mathrm{W}_{4}$ with linear IR spectra of $\mathrm{W}_{4}$ and various $\mathrm{H}^{+} \mathrm{Pym}-\mathrm{W}_{4}$ clusters calculated at the B3LYP-D3/aug-cc-pVTZ level (Table 1).

a new structure with a cyclic $\mathrm{H}$-bonded $\mathrm{W}_{4}$ ring attached to the $\mathrm{NH}$ group of $\mathrm{H}^{+}$Pym $\left(C_{\mathrm{s}}\right)$ is calculated to be the most stable isomer at $T=0 \mathrm{~K}$, with $D_{0}=16675 \mathrm{~cm}^{-1}$. Its additional stability arises from the extra $\mathrm{OH} \cdots \mathrm{O} \mathrm{H}$-bond produced by closing the solvation ring. The enhanced strength of the $\mathrm{NH} \cdots \mathrm{O}$ ionic $\mathrm{H}$-bond in this $\mathrm{H}^{+} \mathrm{Pym}-\mathrm{W}_{4}(\mathrm{r})$ isomer as compared to the most stable $n=3$ structure is rationalized by the higher PA of $\mathrm{W}_{4}$ as compared to $\mathrm{W}_{3}\left(\mathrm{PA}=862 v s .900 \mathrm{~kJ} \mathrm{~mol}^{-1}\right)$. As a result, $R_{\mathrm{NH}} \cdots \mathrm{O}$ becomes shorter (1.464 vs. $1.500 \AA)$, and the $\mathrm{N}-\mathrm{H}$ bond gets longer $\left(\Delta r_{\mathrm{NH}}=16 \mathrm{m \AA}\right)$ which lowers $\nu_{\mathrm{NH}}^{\mathrm{b}}$ further from 2312 to $2088 \mathrm{~cm}^{-1}$. The enhanced strength of the $\mathrm{NH} \cdots \mathrm{O}$ ionic $\mathrm{H}$-bond is further supported by the increased charge transfer to the solvent cluster $(\Delta q=129$ vs. $111 \mathrm{me})$ and the larger $E^{(2)}$ and $\rho^{*}$ values $\left(E^{(2)}=241\right.$ vs. $201 \mathrm{~kJ} \mathrm{~mol}^{-1} ;-\rho^{*}=0.086$ vs. 0.077 a.u. $)$ documented in Fig. S3-S5 in the ESI. $\dagger$ The characteristic $\nu_{\mathrm{OH}}^{\mathrm{b}}$ modes associated with the two single-donor single-acceptor $\mathrm{W}$ ligands are calculated at significantly higher frequencies $\left(\nu_{\mathrm{OH}}^{\mathrm{b}}=3529\right.$ and $\left.3510 \mathrm{~cm}^{-1}\right)$ than those of the other isomers $\left(\nu_{\mathrm{OH}}^{\mathrm{b}}<3500 \mathrm{~cm}^{-1}\right)$, because their H-bonds to the bridging double-acceptor $\mathrm{W}$ ligand are rather weak and long, as also indicated by their NBO and NCI indices. As a result, also the $\nu_{3}$ and $\nu_{1}$ frequencies of the latter ligand are slightly higher than those of the other isomers $\left(3715 / 3630 \mathrm{~cm}^{-1}\right)$.

Attaching a further $\mathrm{W}$ ligand to the $\mathrm{b} 1$ and $\mathrm{b} 2$ isomers of the $n=3$ clusters leads to the corresponding isomers of $n=4$, with a reversed energy order $\left(D_{0}=16471\right.$ and $16537 \mathrm{~cm}^{-1}, E_{0}=204$ and $138 \mathrm{~cm}^{-1}$ ). The stability of b2 exhibiting the $\mathrm{CH} \cdots \mathrm{O}$ $\mathrm{H}$-bond is higher than that of b1 (without such a contact) because of the additional cooperative effects induced by the terminal $\mathrm{W}$ ligand, leading to a shorter $\mathrm{H}$-bond $\left(R_{\mathrm{CH} \cdots \mathrm{O}}=\right.$ 2.386 vs. $2.491 \AA)$ and higher $E^{(2)}$ and $\rho^{*}$ values compared to its $n=3$ analogue $\left(E^{(2)}=8.6\right.$ vs. $5.9 \mathrm{~kJ} \mathrm{~mol}^{-1} ;-\rho^{*}=0.011$ vs. -0.008 a.u.) (Fig. S4 and S5 in the ESI $\dagger$ ). The $\nu_{\mathrm{CH}}^{\mathrm{b}}$ mode at $3063 \mathrm{~cm}^{-1}$ becomes slightly more intense $\left(I_{\mathrm{CH}}=42 \mathrm{~km} \mathrm{~mol}^{-1}\right)$ by this enhanced interaction, which is however still smaller than the additional $\mathrm{OH} \mathrm{OO}$ interaction in the most stable ring $(\mathrm{r})$ isomer, as reflected from its $E^{(2)}$ and $\rho^{*}$ parameters (30 kJ mol ${ }^{-1},-0.025$ a.u.). For cooperativity reasons, also the $\mathrm{NH} \cdots \mathrm{O}$ H-bonds are stronger in the b1/b2 isomers of $n=4$ as compared to $n=3$. Computationally, b2 is the most favoured $n=4$ isomer at $T=298 \mathrm{~K}(G=0)$ due to its larger structural flexibility which enhances the entropic contribution.

Unlike the branched isomers, simple linear addition of a $\mathrm{W}$ ligand to the linear 11 and 12 isomers of $n=3$ converges to the single $n=4$ structure at $E_{0}=163 \mathrm{~cm}^{-1}$. The resulting linear (l) isomer of $n=4$ features a $\mathrm{CH} \cdots \mathrm{O}$ H-bond that renders this isomer more stable than b1. Despite its shorter $R_{\mathrm{CH} \ldots \mathrm{O}}$ distance (2.213 vs. $2.386 \AA$ ), isomer 1 is slightly less stable than b2, which is rationalized by its partially solvated $\mathrm{W}$ ligand adjacent to the $\mathrm{H}^{+}$Pym moiety.

For all $n=4$ isomers, we fail to optimize Pym- $\mathrm{H}^{+} \mathrm{W}_{4}$ structures with the additional proton located at the solvent site, because of barrierless proton transfer leading to formation of the corresponding more stable $\mathrm{H}^{+} \mathrm{Pym}-\mathrm{W}_{4}$ structures. This result is similar to previous computational efforts ${ }^{66,67}$ and at first glance surprising because the proton affinity reported for $\mathrm{W}_{4}$ is substantially higher than that of Pym (PA $=900 v s$. $886 \mathrm{~kJ} \mathrm{~mol}^{-1}$ ), in line with the mass spectrometric observation of exothermic bimolecular proton transfer in ion-molecule reaction (1). ${ }^{66,67}$ The lack of intracluster proton transfer (ICPT) is rationalized by the difference in solvation energies in Pym- $\mathrm{H}^{+} \mathrm{W}_{4}$ and $\mathrm{H}^{+} \mathrm{Pym}-\mathrm{W}_{4}$, which compensates for the difference in the PA of Pym and $\mathrm{W}_{4}$. One has also to keep in mind that the minimum geometries of both cyclic $\mathrm{W}_{4}$ and $\mathrm{H}^{+} \mathrm{W}_{4}$ are not conserved during the formation of conceivable Pym- $\mathrm{H}^{+} \mathrm{W}_{4}$ and $\mathrm{H}^{+}$Pym- $-\mathrm{W}_{4}$ clusters, which also influences the effective PA values of Pym and $\mathrm{W}_{4}$ via solvation and reorganization effects.

The IRPD spectrum of $\mathrm{H}^{+} \mathrm{Pym}-\mathrm{W}_{4}$ is compared in Fig. 10 to the IR spectra predicted for the cyclic, linear, and branched isomers, along with the spectrum computed for cyclic $\mathrm{W}_{4}$. Compared to the IRPD spectra recorded for $n=1-3$, the signal-to-noise ratio of the $n=4$ spectrum is quite low due to the reduced parent ion signal (Fig. 1), making the assignments less certain for the larger hydrate. Three sharp bands $\mathrm{A}$ $\left(3740 \mathrm{~cm}^{-1}\right), \mathrm{C}\left(3716 \mathrm{~cm}^{-1}\right)$, and B $\left(3648 \mathrm{~cm}^{-1}\right)$ are observed in the free $\mathrm{OH}$ stretch range above $3600 \mathrm{~cm}^{-1}$, and assigned to $\nu_{3}, \nu_{\mathrm{f}}$, and $\nu_{1}$, respectively. These are accompanied by a relatively broad and weakly resolved feature between 3000 and $3500 \mathrm{~cm}^{-1}$ in the bound $\mathrm{OH}$ stretch range, which may be divided into transitions D1 $\left(3464 \mathrm{~cm}^{-1}\right), \mathrm{D} 2\left(3393 \mathrm{~cm}^{-1}\right)$, 
D3 $\left(3200 \mathrm{~cm}^{-1}\right)$, and $\mathrm{E}\left(3087 \mathrm{~cm}^{-1}\right)$. The bending overtones of the $\mathrm{W}$ ligands $\left(2 \beta_{\mathrm{OH}}\right.$, band $\left.\mathrm{X}\right)$ may also contribute to some extent to the signal in the spectral range in the vicinity of band D3. Although the quality of the IRPD spectrum is not sufficient to single out the dominating contributing structures, we attempt to tentatively explain the spectrum in terms of the two most stable isomers (which however does not imply the absence of other isomers). Unlike the $n=1-3$ clusters, discernible intensity occurs in the spectral range near $3460 \mathrm{~cm}^{-1}$ (D1), which is characteristic of weakly-bonded $\nu_{\mathrm{OH}}^{\mathrm{b}}$ modes of single-donor singleacceptor $\mathrm{W}$ ligands, and thus a unique signature of the most stable ring isomer, with calculated frequencies of 3529 and $3510 \mathrm{~cm}^{-1}$. The two $\nu_{\mathrm{OH}}^{\mathrm{b}}$ modes of the $\mathrm{W}$ ligand attached to $\mathrm{H}^{+}$Pym (3310 and $3304 \mathrm{~cm}^{-1}$ ) may explain the broad band D3, while the overlapping $\nu_{3}$ and $\nu_{\mathrm{f}}$ modes of the ring isomer at 3715 and $3712 \mathrm{~cm}^{-1}$ are attributed to band $\mathrm{C}$ at $3716 \mathrm{~cm}^{-1}$ and its $\nu_{1}$ mode $\left(3630 \mathrm{~cm}^{-1}\right)$ to the weak feature $\mathrm{B}$ at $3648 \mathrm{~cm}^{-1}$. The free $\mathrm{OH}$ stretch bands $\mathrm{A}-\mathrm{C}$ may also contain $\nu_{3}, \nu_{\mathrm{f}}$, and $\nu_{1}$ modes of the $\mathrm{b} 2$ isomer predicted at $3741 / 3739,3697$, and $3650 / 3649 \mathrm{~cm}^{-1}$, respectively. Its three close lying $\nu_{\mathrm{OH}}^{\mathrm{b}}$ modes at 3423,3380 , and $3348 \mathrm{~cm}^{-1}$ can be ascribed to band D2 $\left(3393 \mathrm{~cm}^{-1}\right)$. We further assign the unique $\mathrm{H}$-bonded and comparatively intense $\nu_{\mathrm{CH}}^{\mathrm{b}}$ mode $\left(3063 \mathrm{~cm}^{-1}\right)$ to the weak band $\mathrm{E}$ $\left(3087 \mathrm{~cm}^{-1}\right)$. The assignment of the experimental spectrum could also be extended to the other isomers, and in fact, the presence of all these low-lying isomers $\left(E_{0}<205 \mathrm{~cm}^{-1}\right)$ seems plausible. The smooth evolution of the IRPD spectra of $\mathrm{H}^{+} \mathrm{Pym}-\mathrm{W}_{n}$ with $n=1-4$ in Fig. 1 does not provide any experimental evidence for ICPT in this size range, in line with our computational results.

\subsection{Effect of solvent environment and cluster growth}

The analysis of the IRPD spectra of $\mathrm{H}^{+} \mathrm{Pym}-\mathrm{L}_{n}$ with $\mathrm{L}=\mathrm{W}(n=$ 1-4) and $\mathrm{L}=\mathrm{N}_{2}(n=1)$ with the aid of DFT calculations provides detailed insight into the preferred protonation site, the acidity of the $\mathrm{NH}$ group, the interaction potential with quadrupolar and dipolar ligands and the evolution of the microhydration network of this fundamental biomolecular building block. Significantly, these IRPD spectra provide the first spectroscopic information about isolated $\mathrm{H}^{+} \mathrm{Pym}$ and its clusters. From the $\mathrm{H}^{+} \mathrm{Pym}-\mathrm{L}_{n}$ spectra it is proven for the first time by spectroscopic means that isolated $\mathrm{H}^{+}$Pym indeed protonates at the $\mathrm{N}$ atom, as suggested from mass spectrometric and quantum chemical studies, ${ }^{66-68}$ as well as condensed phase data. ${ }^{113}$ From the $\mathrm{H}^{+}$Pym- $\mathrm{N}_{2}(\pi)$ spectrum, we derive an accurate value for the $\mathrm{NH}$ stretch frequency as $\nu_{\mathrm{NH}}=3391 \pm 3 \mathrm{~cm}^{-1}$. This value may be compared to $\nu_{\mathrm{NH}}$ frequencies of related aromatic (heterocyclic) ions, such as protonated imidazole $\left(3470 \mathrm{~cm}^{-1}\right),{ }^{84}$ oxazole $\left(3470 \mathrm{~cm}^{-1}\right),{ }^{77}$ 5-hydroxyindole $\left(3405,3478,3503 \mathrm{~cm}^{-1}\right.$ for $\mathrm{C} 3 / \mathrm{C} 4 / \mathrm{O}-$ protonation), ${ }^{79}$ and benzonitrile $\left(3555 \pm 3 \mathrm{~cm}^{-1}\right){ }^{78}$ illustrating that the $\mathrm{NH}$ group of $\mathrm{H}^{+} \mathrm{Pym}$ has a relatively high acidity leading to low $\nu_{\mathrm{NH}}$. As a result, the $\mathrm{NH} \cdots \mathrm{L}$ ionic $\mathrm{H}$-bonds are relatively strong, and the preferred binding motif for both hydrophobic nonpolar ligands $\left(\mathrm{N}_{2}\right)$ and hydrophilic polar ligands (W). Due to the higher $\mathrm{PA}$ of $\mathrm{W}$ as compared to $\mathrm{N}_{2}$ (494 vs. $691 \mathrm{~kJ} \mathrm{~mol}^{-1}$ ), ${ }^{69}$ the $\mathrm{H}$-bond in $\mathrm{H}^{+} \mathrm{Pym}-\mathrm{W}(\mathrm{H})$ is much stronger than in $\mathrm{H}^{+}$Pym- $\mathrm{N}_{2}(\mathrm{H})$, as evident from the larger $D_{0}$ value (5854 vs. $1530 \mathrm{~cm}^{-1}$ ), the shorter $R_{\mathrm{NH} \cdots \mathrm{L}}$ bond (1.688vs. $2.061 \AA$ ), larger values for $E^{(2)}, \rho^{*}$, and $\Delta q$ (94vs. $36 \mathrm{~kJ} \mathrm{~mol}^{-1}, 0.047$ vs. 0.021 a.u., 55 vs. $24 \mathrm{me}$ ), and the larger perturbation of the $\mathrm{NH}$ group $\left(\Delta r_{\mathrm{NH}}=27 v s .6 \mathrm{m \AA}\right),-\Delta \nu_{\mathrm{NH}}=$ 463 vs. $119 \mathrm{~cm}^{-1}, \Delta I_{\mathrm{NH}}=1553$ vs. $594 \mathrm{~km} \mathrm{~mol}^{-1}$. N-protonation of Pym decreases the acidiy of the $\mathrm{C}-\mathrm{H}$ bonds, as illustrated by the increase in the $\nu_{\mathrm{CH}}$ values. Neutral Pym-Ar/ $\mathrm{N}_{2}$ dimers prefer $\pi$-stacking to the aromatic ring because of the dominant dispersion forces between these nonpolar ligands and the aromatic $\pi$-electron system of Pym, and the binding energy of Pym- $\mathrm{N}_{2}(\pi)$ has been estimated as $D_{0}=384 \pm 33 \mathrm{~cm}^{-1}$ from fluorescence spectroscopy. ${ }^{114,115}$ Despite the excess charge, ionization of Pym- $\mathrm{N}_{2}(\pi)$ induces only a minor increase in bond strength $\left(D_{0}=479 \pm 33 \mathrm{~cm}^{-1}\right.$ derived from $\left.\Delta D_{0}=95 \mathrm{~cm}^{-1}\right),{ }^{100}$ because $\mathrm{N}_{2}$ rotates by $90^{\circ}$ upon ionization to optimize the charge-quadrupole and charge-induced dipole forces. On the other hand, our calculations yield $D_{0}=858 \mathrm{~cm}^{-1}$ for $\mathrm{H}^{+} \mathrm{Pym}-\mathrm{N}_{2}(\pi)$, suggesting that protonation changes the preference from $\pi$-stacking to H-bonding $\left(D_{0}=1530 \mathrm{~cm}^{-1}\right)$ because of the high acidity of the newly formed $\mathrm{NH}$ group, so that $\mathrm{H}^{+} \mathrm{Pym}-\mathrm{N}_{2}(\pi)$ is much less abundant than $\mathrm{H}^{+} \mathrm{Pym}-\mathrm{N}_{2}(\mathrm{H})$ in our plasma expansion ( $\sim 20 \%$ ). For the polar $\mathrm{W}$ ligand, this effect is more dramatic because the energy gap between $\pi$-stacking and $\mathrm{H}$-bonding increases from 672 to $2773 \mathrm{~cm}^{-1}$, so that only the $\mathrm{H}^{+} \mathrm{Pym}-\mathrm{W}(\mathrm{H})$ global minimum is detected. The strength of the $\mathrm{NH} \cdots \mathrm{O}$ ionic $\mathrm{H}$-bond in $\mathrm{H}^{+} \mathrm{Pym}-\mathrm{W}$ may be compared to that in related aromatic clusters with an ionic $\mathrm{NH} \cdots \mathrm{W}$ bond, such as protonated benzonitrile $\left(D_{0}=6924 \mathrm{~cm}^{-1}\right),{ }^{50}$ oxazole $\left(D_{0}=6094 \mathrm{~cm}^{-1}\right),{ }^{77}$ imidazole $\left(D_{0}=5836 \mathrm{~cm}^{-1}\right),{ }^{84}$ and 5-hydroxyindole $\left(D_{0}=\right.$ $5040 / 3301 / 4071 \mathrm{~cm}^{-1}$ for C3/O/C4-protonation), ${ }^{79}$ and the radical cations of aminobenzonitrile $\left(D_{0}=6924 \mathrm{~cm}^{-1}\right),{ }^{87}$ pyrrole $\left(D_{0}=5442 \mathrm{~cm}^{-1}\right),{ }^{83}$ 5-hydroxyindole $\left(D_{0}=4422 \mathrm{~cm}^{-1}\right),{ }^{80}$ acetanilide $\left(D_{0}=4513 \mathrm{~cm}^{-1}\right)^{82}$ and trans/cis-formanilide $\left(D_{0}=4897 / 4878 \mathrm{~cm}^{-1}\right) .{ }^{81}$

The evolution of the IRPD spectra of $\mathrm{H}^{+} \mathrm{Pym}-\mathrm{W}_{n}$ with $n=1-4$ show drastic effects upon sequential hydration. Significantly, the IRPD spectra provide for the first time an experimental impression for the microhydration structure of this fundamental protonated biomolecule. The spectra are assigned to the single dominating isomers $\mathrm{H}^{+} \mathrm{Pym}-\mathrm{W}(\mathrm{H}), \mathrm{H}^{+} \mathrm{Pym}-\mathrm{W}_{2}(\mathrm{l1})$, and $\mathrm{H}^{+} \mathrm{Pym}-\mathrm{W}_{3}(\mathrm{~b} 1)$ for $n \leq 3$ and predominantly $\mathrm{H}^{+} \mathrm{Pym}-\mathrm{W}_{4}(\mathrm{r})$ for $n=4$, in which a $\mathrm{H}$-bonded $\mathrm{W}_{n}$ solvent network is attached to the acidic NH proton. For $n=3$, we also identify a less stable linear $\mathrm{H}^{+} \mathrm{Pym}-\mathrm{W}_{3}(\mathrm{l})$ isomer and for $n=4$ there may be more contributing isomers. The computed structures agree well with previous predictions. ${ }^{66,67}$ Our computed sequential hydration energies decrease as $D_{0}=5854>4091>3509>3221 \mathrm{~cm}^{-1}$ for the global minima of $n=1-4$, a trend that is well reproduced by the bond enthalpies measured by mass spectrometry for $n=1-3$ $\left(-\Delta H^{0}=16.7 \pm 1>12.7 \pm 1>11.0 \pm 1 \mathrm{kcal} \mathrm{mol}^{-1}\right.$ or $5840 \pm$ $\left.350>4440 \pm 350>3850 \pm 350 \mathrm{~cm}^{-1}\right) .{ }^{67}$ In general, the proton affinity of $\mathrm{W}_{n}$ increases with cluster size $(\mathrm{PA}=691<808<$ $862<900 \mathrm{~kJ} \mathrm{~mol}^{-1}$ for $\left.n=1-4\right),{ }^{69-72}$ and thus the strength of the $\mathrm{NH} \cdots \mathrm{W}_{n}$ H-bond increases with $n\left(R_{\mathrm{NH} \cdots \mathrm{O}}=1.688>\right.$ $1.588>1.500>1.464 \AA$ for $n=1-4, D_{0}=5849<8842<$ $9534 \sim 9220 \mathrm{~kJ} \mathrm{~mol}^{-1}$ ). This drastic cooperative effect is also visible in the increasing charge transfer from $\mathrm{H}^{+}$Pym to $\mathrm{W}_{n}$ 
$(\Delta q=55<79<111<129 \mathrm{~m} e)$, and the $E^{(2)}$ and $-\rho^{*}$ values of the $\mathrm{NH} \cdots \mathrm{O}$ ionic H-bond $\left(94<141<201<241 \mathrm{~kJ} \mathrm{~mol}^{-1}\right.$; $0.047<0.061<0.077<0.086$ a.u.). The progressive activation of the acidic $\mathrm{NH}$ group by sequential microhydration is documented by the elongation of the $\mathrm{N}-\mathrm{H}$ bond $\left(\Delta r_{\mathrm{NH}}=27<\right.$ $44<68<84 \mathrm{m \AA})$, which goes along with increasing computed $\nu_{\mathrm{NH}}$ redshifts $\left(-\Delta \nu_{\mathrm{NH}}=463<738<1084<1308 \mathrm{~cm}^{-1}\right)$ that are consistent with the measured ones for $n=1-3(516<786<$ at least $950 \mathrm{~cm}^{-1}$ ). In general, there is a monotonic trend for the reduction of $\nu_{\mathrm{NH}}$ with the proton affinity of the solvent (Fig. 11). While the $\nu_{\mathrm{NH}}$ band (F) shifts to the red upon hydration, the bound and free $\mathrm{OH}$ stretch frequencies (A-D) tend to increase by hydration, because of increasing delocalization of the positive partial charge on the solvent cluster. For example, band A $\left(\nu_{3}\right)$ moves from 3717 to $3740 \mathrm{~cm}^{-1}$, band $\mathrm{B}$ $\left(\nu_{1}\right)$ from 3633 to $3648 \mathrm{~cm}^{-1}$, band C $\left(\nu_{\mathrm{f}}\right)$ from 3698 to 3716 , and band $\mathrm{D}(1)$ from 3340 to $3464 \mathrm{~cm}^{-1}$. These experimental trends are fully in line with the predictions.

Up to $n=3$, we do not have any evidence for intracluster proton transfer (ICPT) in $\mathrm{H}^{+} \mathrm{Pym}-\mathrm{W}_{n}$ both experimentally and computationally. This may be expected from the PA values of $\mathrm{W}_{1-3}\left(\mathrm{PA}=691-862 \mathrm{~kJ} \mathrm{~mol}^{-1}\right),{ }^{69-72}$ which are well below that of Pym (886 kJ mol ${ }^{-1}$ ). However, from $n \geq 4$ onwards, the PA of $\mathrm{W}_{n}$ clusters are larger $\left(\mathrm{PA}=900 \mathrm{~kJ} \mathrm{~mol}^{-1}\right.$ for $\left.\mathrm{W}_{4}\right)$ than for Pym so that one may expect ICPT in $\mathrm{H}^{+} \mathrm{Pym}-\mathrm{W}_{n}$ for $n$ larger than a critical size $n_{\mathrm{c}}=4$. However, one has to bear in mind that apart from relative PA values also the solvation energies are important for the determination of $n_{\mathrm{c} \cdot}{ }^{74,90,91,116}$ Indeed, there is indirect evidence from mass spectrometry that proton transfer from $\mathrm{H}^{+}$Pym to $\mathrm{W}_{4}$ is exotherm in bimolecular reactions, leading to the observation of $\mathrm{H}^{+} \mathrm{W}_{4}$ fragment ions, as expected from the PA values. ${ }^{67}$ Multiphoton ionization of neutral Pym- $\mathrm{W}_{m}$ clusters lead to the detection of $\left[\mathrm{Pym}-\mathrm{W}_{n}\right] \mathrm{H}^{+}$fragment clusters with $n<m,{ }^{66}$ which is explained by ionization of the $\mathrm{W}_{m}$ moiety and subsequent elimination of $\mathrm{OH}$ (and further $\mathrm{W}$ ligands). Calculations performed in that work ${ }^{66}$ illustrate that

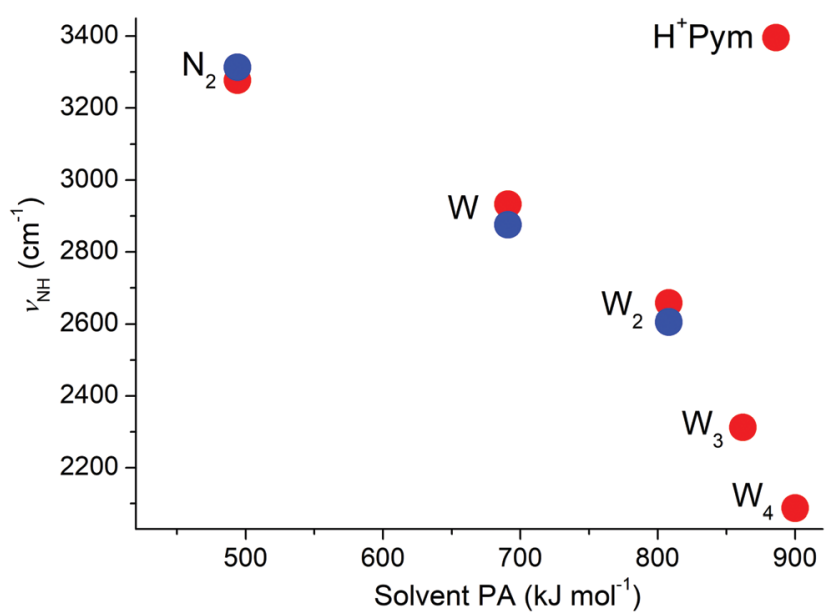

Fig. 11 Observed (blue circles) and calculated (red, B3LYP-D3/aug-ccpVTZ, global minima) $\nu_{\mathrm{NH}}^{\mathrm{b}}$ frequencies of the $\mathrm{H}$-bonded $\mathrm{H}^{+}$Pym-L dimers $\left(\mathrm{L}=\mathrm{N}_{2}, \mathrm{~W}\right)$ and $\mathrm{H}^{+}$Pym $-\mathrm{W}_{n}$ clusters $(n \leq 4)$ as a function of the PA of the ligands. the excess proton in $\left[\mathrm{Pym}-\mathrm{W}_{n}\right] \mathrm{H}^{+}$with $n=1-4$ moves from the $\mathrm{H}^{+} \mathrm{W}_{m}$ solvent to Pym via barrierless ICPT leading to $\mathrm{H}^{+} \mathrm{Pym}-\mathrm{W}_{n}$ structures. These results are consistent with our calculations for $\left[\mathrm{Pym}-\mathrm{W}_{4}\right] \mathrm{H}^{+}$and suggest that for this cluster size the excess proton should be attached to Pym and not to $\mathrm{W}_{4}$, in disagreement with the expectation from the bare PA values. One might argue that the experimental PA of $\mathrm{W}_{n}$ clusters is not a welldefined quantity, because the structures of $\mathrm{W}_{n}$ and $\mathrm{H}^{+} \mathrm{W}_{n}$ are quite different in the bare clusters and also different from the hydration structure within the $\left[\mathrm{Pym}-\mathrm{W}_{n}\right] \mathrm{H}^{+}$heteroclusters. On the other hand, the mass spectrometric evidence from reaction (1) is consistent with an exothermic reaction for $n \geq 4$, indicating that indeed $\mathrm{PA}\left(\mathrm{W}_{4}\right)>\operatorname{PA}(\mathrm{Pym}) .{ }^{66,67}$ Hence, the lack of ICPT in $\mathrm{H}^{+}$Pym- $-\mathrm{W}_{4}$ is attributed to the higher solvation energy compared to $\mathrm{Pym}-\mathrm{H}^{+} \mathrm{W}_{4}$, which overcomes the difference in PA of $\mathrm{W}_{4}$ and Pym. Thus, the critical size for ICPT in $\left[\mathrm{Pym}-\mathrm{W}_{n}\right] \mathrm{H}^{+}$must be $n_{\mathrm{c}}>4$. For comparison, for related closed-shell protonated aromatic ions, such ICPT has been observed for benzene $\left(n_{\mathrm{c}}=1, \mathrm{PA}=746 \mathrm{~kJ} \mathrm{~mol}^{-1}\right),{ }^{90,91}$ naphthalene $\left(n_{\mathrm{c}}=2, \mathrm{PA}=803 \mathrm{~kJ} \mathrm{~mol}^{-1}\right),{ }^{86,88}$ benzonitrile $\left(n_{\mathrm{c}}=2, \mathrm{PA}=812 \mathrm{~kJ} \mathrm{~mol}^{-1}\right),{ }^{50}$ benzaldehyde $\left(n_{\mathrm{c}}=3, \mathrm{PA}=\right.$ $\left.834 \mathrm{~kJ} \mathrm{~mol}^{-1}\right),{ }^{85}$ and phenol $\left(n_{\mathrm{c}}=3, \mathrm{PA}=817 \mathrm{~kJ} \mathrm{~mol}^{-1}\right),{ }^{89}$ but not for aniline up to $n=6\left(\mathrm{PA}=883 \mathrm{~kJ} \mathrm{~mol}^{-1}\right) \cdot{ }^{117}$

It is instructive to compare $\mathrm{H}^{+} \mathrm{Pym}-\mathrm{W}_{n}$ with neutral Pym- $\mathrm{W}_{n}$ to evaluate the drastic effects of protonation on microhydration with respect to both the interaction energy and the structure of the H-bonded solvent network. The geometry and bonding of neutral Pym $-\mathrm{W}_{n}$ clusters have been characterized by microwave $(n=1),{ }^{92}$ matrix isolation IR $(n=1-2),{ }^{93}$ and multiphoton ionization spectroscopy $(n=1-6),{ }^{66}$ along with quantum chemical calculations $(n=1-2)$. Pym-W adopts a coplanar structure with a $\mathrm{OH} \cdots \mathrm{N}$ H-bond between the $\mathrm{OH}$ donor of $\mathrm{W}$ and the basic $\mathrm{N}$ atom of Pym as acceptor. This neutral $\mathrm{OH} \cdots \mathrm{N}$ $\mathrm{H}$-bond is much weaker and longer $\left(D_{0}=1790 \mathrm{~cm}^{-1}, R_{\mathrm{OH} \cdots \mathrm{N}}=\right.$ $1.946 \AA$, Fig. S8 in the ESI $\dagger$ ) than the $\mathrm{NH} \cdots \mathrm{O}$ ionic $\mathrm{H}$-bond in $\mathrm{H}^{+}$Pym-W(H) between the highly acidic $\mathrm{NH}$ proton donor and $\mathrm{W}$, which is stabilized by strong cation-dipole forces $\left(D_{0}=5854 \mathrm{~cm}^{-1}, R_{\mathrm{NH} \cdots \mathrm{O}}=1.688 \AA\right)$. Furthermore, the structures computed for Pym- $\mathrm{W}_{2}$ have an $\mathrm{H}$-bonded hydration network incorporating the neighboring $\mathrm{CH}$ group as weak proton donor or forming a second $\mathrm{H}$-bond to the highly basic second $\mathrm{N}$ atom of Pym as proton acceptor. ${ }^{66,93}$ Thus, the additional acidic proton in $\mathrm{H}^{+}$Pym strongly increases the interaction with $\mathrm{W}_{n}$ and forms hydration motifs in which the $\mathrm{W}_{n}$ solvent cluster grows away from the aromatic molecule because of the strong anisotropy of the dominant cation-dipole interaction absent the neutral cluster.

\section{Concluding remarks}

In summary, we combine IRPD spectroscopy of mass-selected $\mathrm{H}^{+}$Pym- $\mathrm{L}_{n}$ clusters with $\mathrm{L}=\mathrm{W}(n=1-4)$ and $\mathrm{L}=\mathrm{N}_{2}(n=1)$ in the sensitive $\mathrm{CH}, \mathrm{NH}$, and $\mathrm{OH}$ stretch range with DFT calculations at the B3LYP-D3/aug-cc-pVTZ level to unravel the solvation structure around this protonated biomolecular building block. 
Significantly, these spectra provide the first spectroscopic information about isolated $\mathrm{H}^{+} \mathrm{Pym}$ and its clusters with nonpolar and polar ligands. As such, they serve as benchmark for the interaction of protonated nucleobases with a polar hydrophilic protic solvent $(\mathrm{W})$ and a nonpolar hydrophobic aprotic solvent $\left(\mathrm{N}_{2}\right)$. The salient results may be summarized as follows. In agreement with previous indirect mass spectrometric data and quantum chemical calculations, ${ }^{66-68}$ as well as condensed phase measurements, ${ }^{113}$ the analysis of the $\mathrm{H}^{+} \mathrm{Pym}-\mathrm{L}_{n}$ spectra provide the first unambiguous spectroscopic evidence that isolated $\mathrm{H}^{+}$Pym has a strong energetic preference $\left(>200 \mathrm{~kJ} \mathrm{~mol}^{-1}\right)$ for protonation at one of the two equivalent basic $\mathrm{N}$ atoms rather than at the $\mathrm{C}$ atoms. This is expected because C-protonation strongly perturbs the stability of the aromatic $\pi$-electron system. The $\mathrm{H}^{+}$Pym $-\mathrm{N}_{2}$ spectrum is interpreted with the more stable $\mathrm{H}$-bonded $\mathrm{H}^{+} \mathrm{Pym}-\mathrm{N}_{2}(\mathrm{H})$ global minimum and a minor contribution of the less stable stacked $\mathrm{H}^{+} \mathrm{Pym}-\mathrm{N}_{2}(\pi)$ isomer $(\sim 20 \%)$. From the latter spectrum, the $\nu_{\mathrm{NH}}$ frequency of bare $\mathrm{H}^{+}$Pym is extracted as $3391 \pm 3 \mathrm{~cm}^{-1}$. Moreover, the $\nu_{\mathrm{CH}}$ frequencies of $\mathrm{H}^{+}$Pym are higher than those in neutral Pym, indicating that $\mathrm{N}$-protonation strengthens the aromatic $\mathrm{C}-\mathrm{H}$ bonds. The $\mathrm{H}^{+}$Pym-W spectrum is interpreted with a single $\mathrm{H}$-bonded $\mathrm{H}^{+} \mathrm{Pym}-\mathrm{W}(\mathrm{H})$ isomer, and its linear $\mathrm{NH} \cdots \mathrm{W}$ ionic $\mathrm{H}$-bond is much stronger than the $\mathrm{NH} \cdots \mathrm{N}_{2} \mathrm{H}$-bond in $\mathrm{H}^{+} \mathrm{Pym}-\mathrm{N}_{2}(\mathrm{H})$ because of the higher PA of the ligand. In the larger $\mathrm{H}^{+}$Pym- $\mathrm{W}_{n}$ clusters, a H-bonded $\mathrm{W}_{n}$ cluster is attached to the acidic $\mathrm{NH}$ group. Thus, the formation of a $\mathrm{H}$-bonded hydration network (external solvation) supported by large cooperative threebody effects arising from induction forces is strongly preferred to interior ion solvation suffering from small noncooperative threebody effects arising from charge delocalization. For increasing $n$, the PA of $\mathrm{W}_{n}$ increases, and as a result the $\mathrm{NH}$ group is progressively activated upon sequential microhydration. However, no intracluster proton transfer from $\mathrm{H}^{+}$Pym to $\mathrm{W}_{n}$ is observed in $\mathrm{H}^{+}$Pym- $-\mathrm{W}_{n}$ for the size range $n \leq 4$, although the PA of $\mathrm{W}_{4}$ exceeds the one of Pym by $14 \mathrm{~kJ} \mathrm{~mol}^{-1}$. This result demonstrates that the PA values is not the only criterion for determining the threshold size for ICPT, and differences in solvation energies must be taken into account as well. Thus, the critical size for ICPT in $\left[\mathrm{Pym}-\mathrm{W}_{n}\right] \mathrm{H}^{+}$must be $n_{\mathrm{c}} \geq 5$, and the determination of its exact value remains as a challenging topic of future computational and experimental work. Although the IRPD spectra (at least for $n \leq 3$ ) are well assigned by the most stable static structures at $T=0 \mathrm{~K}\left(E_{0}\right)$ as well as $T=289.15 \mathrm{~K}(G)$ including at least part of entropic effects at elevated temperatures, it would be interesting to perform molecular dynamics simulations to unravel dynamical effects in more detail. Comparison of the properties of $\mathrm{H}^{+} \mathrm{Pym}-\mathrm{W}_{n}$ with those of neutral Pym- $\mathrm{W}_{n}$ clusters reveals the drastic effects of protonation on microhydration, with respect to both their $\mathrm{H}$-bonded structures and their interaction strength.

\section{Conflicts of interest}

There are no conflicts to declare.

\section{Acknowledgements}

This study was supported by Deutsche Forschungsgemeinschaft (DFG, project DO 729/3-3).

\section{References}

1 K. Wei, E. Karen and W. Joanne, Curr. Drug Metab., 2004, 5, 63-84.

2 W. Saegner, Principles of Nucleic Acid Structure, SpringerVerlag New York, 1984.

3 D. Armentano, G. De Munno, L. Di Donna, G. Sindona, G. Giorgi and L. Salvini, J. Am. Soc. Mass Spectrom, 2004, 15, 268-279.

4 S. Y. Han, S. H. Lee, J. Chung and H. B. Oh, J. Chem. Phys., 2007, 127, 245102.

5 D. Leitner, W. Schröder and K. Weisz, J. Am. Chem. Soc., 1998, 120, 7123-7124.

6 S. W. Powell, L. Jiang and I. M. Russu, Biochemistry, 2001, 40, 11065-11072.

7 L. D. Williams and B. R. Shaw, Proc. Natl. Acad. Sci. U. S. A., 1987, 84, 1779.

8 C. H. Kang, I. Berger, C. Lockshin, R. Ratliff, R. Moyzis and A. Rich, Proc. Natl. Acad. Sci. U. S. A., 1994, 91, 11636.

9 C. Kang, I. Berger, C. Lockshin, R. Ratliff, R. Moyzis and A. Rich, Proc. Natl. Acad. Sci. U. S. A., 1995, 92, 3874.

10 D. E. Draper, $R N A, 2004$, 10, 335-343.

11 U. Nagaswamy, M. Larios-Sanz, J. Hury, S. Collins, Z. Zhang, Q. Zhao and G. E. Fox, Nucleic Acids Res., 2002, 30, 395-397.

12 S. Lemieux and F. Major, Nucleic Acids Res., 2006, 34, 2340-2346.

13 C. Marian, D. Nolting and R. Weinkauf, Phys. Chem. Chem. Phys., 2005, 7, 3306-3316.

14 D. Nolting, C. Marian and R. Weinkauf, Phys. Chem. Chem. Phys., 2004, 6, 2633-2640.

15 D. Nolting, R. Weinkauf, I. V. Hertel and T. Schultz, ChemPhysChem, 2007, 8, 751-755.

16 J.-P. Schermann, Spectroscopy and Modeling of Biomolecular Building Blocks, Elsevier, Amsterdam, 2008.

17 J. L. Wilcox, A. K. Ahluwalia and P. C. Bevilacqua, Acc. Chem. Res., 2011, 44, 1270-1279.

18 J. E. Gee and D. M. Miller, Am. J. Med. Sci., 1992, 304, 366-372.

19 M. D. Frank-Kamenetskii and S. M. Mirkin, Annu. Rev. Biochem., 1995, 64, 65-95.

20 E. N. Nikolova, G. B. Goh, C. L. Brooks and H. M. AlHashimi, J. Am. Chem. Soc., 2013, 135, 6766-6769.

21 I. Berger, C. Kang, A. Fredian, R. Ratliff, R. Moyzis and A. Rich, Nat. Struct. Biol., 1995, 2, 416-425.

22 J. L. Asensio, A. N. Lane, J. Dhesi, S. Bergqvist and T. Brown, J. Mol. Biol., 1998, 275, 811-822.

23 S. M. Mirkin, Nature, 2007, 447, 932-940.

24 K. M. Vasquez, L. Narayanan and P. M. Glazer, Science, 2000, 290, 530.

25 P. B. Dervan, Bioorg. Med. Chem., 2001, 9, 2215-2235. 
26 D. Zhong, S. K. Pal and A. H. Zewail, Chem. Phys. Lett., 2011, 503, 1-11.

27 P. Ball, Chem. Rev., 2008, 108, 74-108.

28 Y. Levy and J. N. Onuchic, Annu. Rev. Biophys. Biomol. Struct., 2006, 35, 389-415.

29 M. Chaplin, Nat. Rev. Mol. Cell Biol., 2006, 7, 861-866.

30 S. K. Pal and A. H. Zewail, Chem. Rev., 2004, 104, 2099-2124.

31 B. Bagchi, Chem. Rev., 2005, 105, 3197-3219.

32 C. Mattos, Trends Biochem. Sci., 2002, 27, 203-208.

33 B. Halle and V. P. Denisov, Biopolymers, 1998, 48, 210-233.

34 B. Schneider, D. Cohen and H. M. Berman, Biopolymers, 1992, 32, 725-750.

35 M. Feig and B. M. Pettitt, Biopolymers, 1998, 48, 199-209.

36 H. R. Drew and R. E. Dickerson, J. Mol. Biol., 1981, 151, 535-556.

37 E. Liepinsh, G. Otting and K. Wüthrich, Nucleic Acids Res., 1992, 20, 6549-6553.

38 B. Nguyen, S. Neidle and W. D. Wilson, Acc. Chem. Res., 2009, 42, 11-21.

39 S. K. Pal, L. Zhao and A. H. Zewail, Proc. Natl. Acad. Sci. U. S. A., 2003, 100, 8113.

40 T. V. Chalikian, G. E. Plum, A. P. Sarvazyan and K. J. Breslauer, Biochemistry, 1994, 33, 8629-8640.

41 T. V. Chalikian, J. Völker, A. R. Srinivasan, W. K. Olson and K. J. Breslauer, Biopolymers, 1999, 50, 459-471.

42 C. L. Perrin and J. B. Nielson, Annu. Rev. Phys. Chem., 1997, 48, 511-544.

43 M. R. A. Blomberg and P. E. M. Siegbahn, Biochim. Biophys. Acta, Bioenerg., 2006, 1757, 969-980.

44 H. Ishikita and K. Saito, J. R. Soc., Interface, 2014, 11, 20130518.

45 B. Giese and S. Wessely, Chem. Commun., 2001, 2108-2109.

46 A. Filippi, C. Fraschetti, F. Rondino, S. Piccirillo, V. Steinmetz, L. Guidoni and M. Speranza, Int. J. Mass Spectrom., 2013, 354-355, 54-61.

47 P. Hobza and K. M. Dethlefs, Non-Covalent Interactions: Theory and Experiment, Royal Society of Chemistry, Cambridge, UK, 2009.

48 M. S. de Vries and P. Hobza, Annu. Rev. Phys. Chem., 2007, 58, 585-612.

49 K. Chatterjee and O. Dopfer, Chem. Sci., 2018, 9, 2301-2318.

50 K. Chatterjee and O. Dopfer, Phys. Chem. Chem. Phys., 2019, 21, 25226-25246.

51 K. Chatterjee, Y. Matsumoto and O. Dopfer, Angew. Chem., Int. Ed., 2019, 58, 3351-3355.

52 O. Dopfer, Z. Phys. Chem., 2005, 219, 125-168.

53 O. Dopfer and M. Fujii, Chem. Rev., 2016, 116, 5432-5463.

54 E. D. Raczyńska, J. F. Gal, P. C. Maria, K. Zientara and M. Szelag, Anal. Bioanal. Chem., 2007, 389, 1365-1380.

55 J. K. Lee, Int. J. Mass Spectrom., 2005, 240, 261-272.

56 R. Wu and T. B. McMahon, J. Am. Chem. Soc., 2007, 129, 569-580.

57 A. Zhachkina, M. Liu, X. Sun, F. S. Amegayibor and J. K. Lee, J. Org. Chem., 2009, 74, 7429-7440.

58 S. $\varnothing$. Pedersen, C. S. Byskov, F. Turecek and S. B. Nielsen, J. Phys. Chem. A, 2014, 118, 4256-4265.
59 M. Pitzer, C. Ozga, C. Küstner-Wetekam, P. Reiß, A. Knie, A. Ehresmann, T. Jahnke, A. Giuliani and L. Nahon, J. Phys. Chem. A, 2019, 123, 3551-3557.

60 M. Nuevo, S. N. Milam, S. A. Sandford, J. E. Elsila and J. P. Dworkin, Astrobiology, 2009, 9, 683-695.

61 P. P. Bera, M. Nuevo, S. N. Milam, S. A. Sandford and T. J. Lee, J. Chem. Phys., 2010, 133, 104303.

62 E. Mendoza, G. C. Almeida, D. P. P. Andrade, H. Luna, W. Wolff, M. L. M. Rocco and H. M. Boechat-Roberty, Mon. Not. R. Astron. Soc., 2013, 433, 3440-3452.

63 P. G. Stoks and A. W. Schwartz, Nature, 1979, 282, 709-710.

64 P. G. Stoks and A. W. Schwartz, Geochim. Cosmochim. Acta, 1981, 45, 563-569.

65 M. P. Callahan, K. E. Smith, H. J. Cleaves, J. Ruzicka, J. C. Stern, D. P. Glavin, C. H. House and J. P. Dworkin, Proc. Natl. Acad. Sci. U. S. A., 2011, 108, 13995.

66 B. Zhang, Y. Cai, X. Mu, N. Lou and X. Wang, J. Chem. Phys., 2002, 117, 3701-3710.

67 A. M. Hamid, P. Sharma, M. Samy El-Shall, R. Hilal, S. Elroby, S. G. Aziz and A. O. Alyoubi, J. Chem. Phys., 2013, 139, 084304.

68 V. Q. Nguyen and F. Tureček, J. Am. Chem. Soc., 1997, 119, 2280-2290.

69 E. P. L. Hunter and S. G. Lias, J. Phys. Chem. Ref. Data, 1998, 27, 413-656.

70 D. J. Goebbert and P. G. Wenthold, Eur. J. Mass Spectrom., 2004, 10, 837-845.

71 A. Courty, M. Mons, J. Le Calvé, F. Piuzzi and I. Dimicoli, J. Phys. Chem. A, 1997, 101, 1445-1450.

72 R. Knochenmuss, O. Cheshnovsky and S. Leutwyler, Chem. Phys. Lett., 1988, 144, 317-323.

73 M. Miyazaki, A. Fujii, T. Ebata and N. Mikami, Chem. Phys. Lett., 2004, 399, 412-416.

74 K. Chatterjee and O. Dopfer, Phys. Chem. Chem. Phys., 2017, 19, 32262-32271.

75 I. K. Attah, S. P. Platt, M. Meot-Ner, M. S. El-Shall, S. G. Aziz and A. O. Alyoubi, Chem. Phys. Lett., 2014, 613, 45-53.

76 A. Patzer, M. Schütz, T. Möller and O. Dopfer, Angew. Chem., Int. Ed., 2012, 51, 4925-4929.

77 K. Chatterjee and O. Dopfer, J. Phys. Chem. A, 2019, 123, 7637-7650.

78 K. Chatterjee and O. Dopfer, Astrophys. J., 2018, 865, 114.

79 J. Klyne and O. Dopfer, Phys. Chem. Chem. Phys., 2019, 21, 2706-2718.

80 J. Klyne, M. Miyazaki, M. Fujii and O. Dopfer, Phys. Chem. Chem. Phys., 2018, 20, 3092-3108.

81 J. Klyne, M. Schmies, M. Fujii and O. Dopfer, J. Phys. Chem. B, 2015, 119, 1388-1406.

82 J. Klyne, M. Schmies, M. Miyazaki, M. Fujii and O. Dopfer, Phys. Chem. Chem. Phys., 2018, 20, 3148-3164.

83 M. Schütz, Y. Matsumoto, A. Bouchet, M. Öztürk and O. Dopfer, Phys. Chem. Chem. Phys., 2017, 19, 3970-3986.

84 H.-S. Andrei, N. Solcà and O. Dopfer, ChemPhysChem, 2006, 7, 107-110.

85 O. Dopfer, A. Patzer, S. Chakraborty, I. Alata, R. Omidyan, M. Broquier, C. Dedonder and C. Jouvet, J. Chem. Phys., 2014, 140, 124314. 
86 K. Chatterjee and O. Dopfer, J. Phys. Chem. A, 2020, 124, 1134-1151.

87 M. Schmies, M. Miyazaki, M. Fujii and O. Dopfer, J. Chem. Phys., 2014, 141, 214301.

88 I. Alata, M. Broquier, C. Dedonder-Lardeux, C. Jouvet, M. Kim, W. Y. Sohn, S.-s. Kim, H. Kang, M. Schütz, A. Patzer and O. Dopfer, J. Chem. Phys., 2011, 134, 074307.

89 M. Katada and A. Fujii, J. Phys. Chem. A, 2018, 122, 5822-5831.

90 E. S. Kryachko and M. T. Nguyen, J. Phys. Chem. A, 2001, 105, 153-155.

91 T. C. Cheng, B. Bandyopadhyay, J. D. Mosley and M. A. Duncan, J. Am. Chem. Soc., 2012, 134, 13046-13055.

92 S. Melandri, M. E. Sanz, W. Caminati, P. G. Favero and Z. Kisiel, J. Am. Chem. Soc., 1998, 120, 11504-11509.

93 A. Destexhe, J. Smets, L. Adamowicz and G. Maes, J. Phys. Chem., 1994, 98, 1506-1514.

94 O. Dopfer, Int. Rev. Phys. Chem., 2003, 22, 437-495.

95 M. J. Frisch, et al., Gaussian 09, version D.01, Gaussian, Inc., Wallingford, CT, 2009.

96 B. E. Rocher-Casterline, L. C. Ch'ng, A. K. Mollner and H. Reisler, J. Chem. Phys., 2011, 134, 211101.

97 K. Sharkas, K. Wagle, B. Santra, S. Akter, R. R. Zope, T. Baruah, K. A. Jackson, J. P. Perdew and J. E. Peralta, Proc. Natl. Acad. Sci. U. S. A., 2020, 201921258.

98 L. Bokobza-Sebagh and J. Zarembowitch, Spectrochim. Acta, Part A, 1976, 32, 797-805.

99 K. K. Innes, I. G. Ross and W. R. Moomaw, J. Mol. Spectrosc., 1988, 132, 492-544.

100 S. Sato, K. Omiya and K. Kimura, J. Electron Spectrosc. Relat. Phenom., 1998, 97, 121-129.

101 G. Herzberg, Molecular Spectra and Molecular Structure. II. Infrared and Raman Spectra of Polyatomic Molecules, Krieger Publishing Company, Malabar, FL, 1991.

102 A. E. Reed, L. A. Curtiss and F. Weinhold, Chem. Rev., 1988, 88, 899-926.

103 E. R. Johnson, S. Keinan, P. Mori-Sánchez, J. Contreras-García, A. J. Cohen and W. Yang, J. Am. Chem. Soc., 2010, 132, 6498-6506.
104 J. Contreras-García, E. R. Johnson, S. Keinan, R. Chaudret, J.-P. Piquemal, D. N. Beratan and W. Yang, J. Chem. Theory Comput., 2011, 7, 625-632.

105 L. Fernholt and C. Romming, Acta Chem. Scand., 1978, 32, 271-273.

106 R. C. Lord, A. L. Marston and F. A. Miller, Spectrochim. Acta, 1957, 9, 113-125.

107 Z. N. Heim, B. K. Amberger, B. J. Esselman, J. F. Stanton, R. C. Woods and R. J. McMahon, J. Chem. Phys., 2020, 152, 104303.

108 S. Albert and M. Quack, J. Mol. Spectrosc., 2007, 243, 280-291.

109 F. Milani-Nejad and H. D. Stidham, Spectrochim. Acta, Part A, 1975, 31, 1433-1453.

110 A. G. Császár, G. Czakó, T. Furtenbacher, J. Tennyson, V. Szalay, S. V. Shirin, N. F. Zobov and O. L. Polyansky, J. Chem. Phys., 2005, 122, 214305.

111 D. Roth and O. Dopfer, Phys. Chem. Chem. Phys., 2002, 4, 4855-4865.

112 R. V. Olkhov and O. Dopfer, Chem. Phys. Lett., 1999, 314, 215-222.

113 J. Riand, M. T. Chenon and N. Lumbroso-Bader, J. Am. Chem. Soc., 1977, 99, 6838-6845.

114 H. Abe, Y. Ohyanagi, M. Ichijo, N. Mikami and M. Ito, J. Phys. Chem., 1985, 89, 3512-3521.

115 N. Mikami, Y. Sugahara and M. Ito, J. Phys. Chem., 1986, 90, 2080-2085.

116 D. Bing, T. Hamashima, C.-W. Tsai, A. Fujii and J.-L. Kuo, Chem. Phys., 2013, 421, 1-9.

117 T. M. Chang, J. S. Prell, E. R. Warrick and E. R. Williams, J. Am. Chem. Soc., 2012, 134, 15805-15813.

118 Z. S. Huang and R. E. Miller, J. Chem. Phys., 1989, 91, 6613-6631.

119 F. Huisken, M. Kaloudis and A. Kulcke, J. Chem. Phys., 1996, 104, 17-25.

120 K. Kuyanov-Prozument, M. Y. Choi and A. F. Vilesov, J. Chem. Phys., 2010, 132, 014304. 